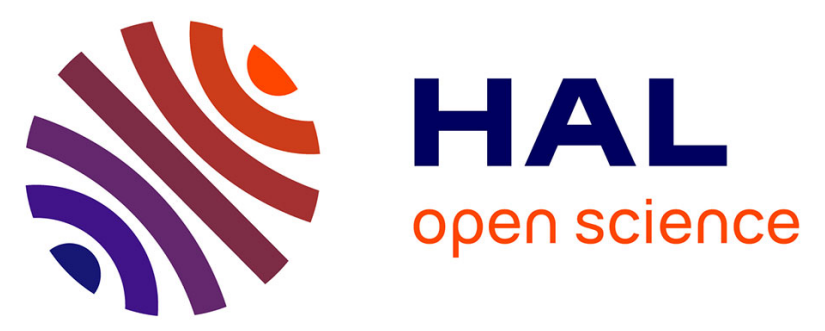

\title{
Novel LMNA mutations in patients with Emery-Dreifuss muscular dystrophy and functional characterization of four LMNA mutations
}

Juergen Scharner, Charlotte A Brown, Matthew Bower, Susan T Iannaccone, Ismail A Khatri, Diana Escolar, Erynn Gordon, Kevin Felice, Carol A Crowe, Carla Grosmann, et al.

\section{To cite this version:}

Juergen Scharner, Charlotte A Brown, Matthew Bower, Susan T Iannaccone, Ismail A Khatri, et al.. Novel LMNA mutations in patients with Emery-Dreifuss muscular dystrophy and functional characterization of four LMNA mutations. Human Mutation, 2011, 32 (2), pp.152. 10.1002/humu.21361. hal-00610794

\section{HAL Id: hal-00610794 \\ https://hal.science/hal-00610794}

Submitted on 25 Jul 2011

HAL is a multi-disciplinary open access archive for the deposit and dissemination of scientific research documents, whether they are published or not. The documents may come from teaching and research institutions in France or abroad, or from public or private research centers.
L'archive ouverte pluridisciplinaire HAL, est destinée au dépôt et à la diffusion de documents scientifiques de niveau recherche, publiés ou non, émanant des établissements d'enseignement et de recherche français ou étrangers, des laboratoires publics ou privés. 


\section{Human Mutation}

WILEY

\section{Novel LMNA mutations in patients with Emery-Dreifuss muscular dystrophy and functional characterization of four LMNA mutations}

\begin{tabular}{|c|c|}
\hline Journal: & Human Mutation \\
\hline Manuscript ID: & humu-2010-0292.R1 \\
\hline Wiley - Manuscript type: & Research Article \\
\hline $\begin{array}{r}\text { Date Submitted by the } \\
\text { Author: }\end{array}$ & 14-Aug-2010 \\
\hline Complete List of Authors: & $\begin{array}{l}\text { Scharner, Juergen; King's College London, Randall Division of Cell } \\
\text { and Molecular Biophysics } \\
\text { Brown, Charlotte; BD Diagnostics } \\
\text { Bower, Matthew; Fairview-University Medical Center, Department of } \\
\text { Pediatrics } \\
\text { Iannaccone, Susan; UT Southwestern Medical Center, Texas } \\
\text { Scottish Rite Hospital for Children } \\
\text { Khatri, Ismail; Shifa International Hospital, Division of Neurology } \\
\text { Escolar, Diana; Children's National Medical Center, Research Center } \\
\text { for Genetic Medicine } \\
\text { Gordon, Erynn; Coriell Institute for Medical Research } \\
\text { Felice, Kevin; Hospital for Special Care, Department of } \\
\text { Neuromuscular Medicine } \\
\text { Crowe, Carol; MetroHealth Medical Center, Department of Pediatrics } \\
\text { Grosmann, Carla; Rady Children's Hospital San Diego, Department } \\
\text { of Neurology } \\
\text { Meriggioli, Matthew; University of Illinois, Department of Neurology } \\
\text { and Rehabilitation } \\
\text { Asamoah, Alexander; Weisskopf Child Evaluation Center, University } \\
\text { of Louisville, Department of Pediatrics } \\
\text { Gordon, Ora; Cedar-Sinai Medical Center, Medical Genetics Institute } \\
\text { Gnocchi, Viola; King's College London, Randall Division of Cell and } \\
\text { Molecular Biophysics } \\
\text { Ellis, Juliet; King's College London, Randall Division of Cell and } \\
\text { Molecular Biophysics } \\
\text { Mendell, Jerry; Ohio State University, and the Research Institute at } \\
\text { Nationwide Children's Hospital, Departments of Pediatrics and } \\
\text { Neurology } \\
\text { Zammit, Peter; king's College London, Randall Division of Cell and } \\
\text { Molecular Biophysics }\end{array}$ \\
\hline Key Words: & $\begin{array}{l}\text { lamin A, lamin B, emerin, EDMD, LGMD, L-CMD, nuclear envelope, } \\
\text { nuclear lamina, laminopathy, skeletal muscle }\end{array}$ \\
\hline
\end{tabular}




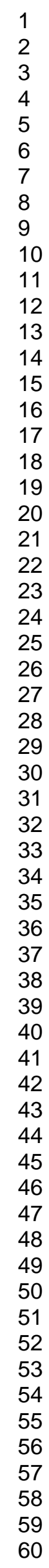

SCHOLARONE ${ }^{m}$
Manuscripts

John Wiley \& Sons, Inc. 


\title{
Novel LMNA mutations in patients with Emery-Dreifuss muscular dystrophy and functional characterization of four $L M N A$ mutations
}

\author{
Juergen Scharner, ${ }^{1,15}$ Charlotte A. Brown, ${ }^{2,15}$ Matthew Bower, ${ }^{3}$ Susan T. Iannaccone, ${ }^{4}$ Ismail A. \\ Khatri, ${ }^{5}$ Diana Escolar, ${ }^{6}$ Erynn Gordon, ${ }^{7}$ Kevin Felice,${ }^{8}$ Carol A. Crowe,${ }^{9}$ Carla Grosmann,,${ }^{10}$ Matthew \\ N. Meriggioli, ${ }^{11}$ Alexander Asamoah, ${ }^{12}$ Ora Gordon, ${ }^{13}$ Viola F. Gnocchi, ${ }^{1}$ Juliet A. Ellis, ${ }^{1}$ Jerry R. \\ Mendell, ${ }^{14} *$ Peter S. Zammit ${ }^{1} *$
}

${ }^{1}$ Randall Division of Cell and Molecular Biophysics, King's College London, UK;

${ }^{2}$ BD Diagnostics, Durham, NC, USA;

${ }^{3}$ Department of Pediatrics, Fairview-University Medical Center, Minneapolis, MN;

${ }^{4}$ Texas Scottish Rite Hospital for Children, UT Southwestern Medical Center, Dallas, TX;

${ }^{5}$ Division of Neurology, Shifa International Hospital, Islamabad, Pakistan;

${ }^{6}$ Research Center for Genetic Medicine, Children's National Medical Center, Washington, D.C.;

${ }^{7}$ Coriell Institute for Medical Research, Camden, NJ

${ }^{8}$ Department of Neuromuscular Medicine, Hospital for Special Care, New Britain, CT;

${ }^{9}$ Department of Pediatrics, MetroHealth Medical Center, Cleveland, OH;

${ }^{10}$ Department of Neurology, Rady Children's Hospital San Diego, San Diego, CA;

${ }^{11}$ Department of Neurology and Rehabilitation, University of Illinois, Chicago, IL;

${ }^{12}$ Department of Pediatrics, Weisskopf Child Evaluation Center, University of Louisville, KY;

${ }^{13}$ Medical Genetics Institute, Cedar-Sinai Medical Center, Los Angeles, CA;

${ }^{14}$ Department of Pediatrics and Neurology, Ohio State University, and the Research Institute at Nationwide Children's Hospital, Columbus, $\mathrm{OH}$;

${ }^{15}$ These authors contributed equally to this work

* These authors are joint last authors.

Correspondence to: peter.zammit@kcl.ac.uk; jerry.mendell@nationwidechildrens.org 


\section{Abstract}

Mutations in LMNA cause a variety of diseases affecting striated muscle including autosomalEmery-Dreifuss muscular dystrophy (EDMD), LMNA-associated congenital muscular dystrophy (L-CMD) and limb-girdle muscular dystrophy type 1B (LGMD1B). Here, we describe novel and recurrent $L M N A$ mutations identified in 50 patients from the USA and Canada, which is the first report of the distribution of LMNA mutations from a large cohort outside Europe. This augments the number of LMNA mutations known to cause EDMD by $16.5 \%$, equating to an increase of $5.9 \%$ in the total known LMNA mutations. Eight patients presented with p.R249W/Q or p.E358K mutations and an early onset EDMD phenotype: two mutations recently associated with L-CMD. Importantly, 15 mutations are novel and include eight missense mutations (p.R189P, p.F206L, p.S268P, p.S295P, p.E361K, p.G449D, p.L454P and p.W467R), three splice site mutations (c.IVS4+1G>A, c.IVS6-2A>G, c.IVS8+1G>A), one duplication/in frame insertion (p.R190dup), one deletion (p.Q355del) and two silent mutations (p.R119R and p.K270K). Analysis of 4 of our lamin A mutations showed that some caused nuclear deformations and lamin B re-distribution in a mutation specific manner. Together, this study significantly augments the number of EDMD patients on the database and describes 15 novel mutations that underlie EDMD, which will contribute to establishing genotype-phenotype correlations.

Keywords: lamin A, lamin B, emerin, EDMD, LGMD, L-CMD, nuclear envelope, nuclear lamina, laminopathy, skeletal muscle 


\section{Introduction}

Emery-Dreifuss muscular dystrophy (EDMD) manifests in childhood with slowly progressive muscle weakness with a scapulo-humeroperoneal distribution, associated with contractures of the Achilles tendon, neck and elbow. Cardiac involvement is a consistent feature associated with nearly all patients by the third decade, initially involving arrhythmias, progressing towards complete heart block with a substantial risk of sudden death in middle age (Emery, 1989).

Both X-linked and autosomal forms of EDMD have been described. Mutations in the EMD gene (Xq28, MIM\# 300384) have been identified in patients with X-linked EDMD (XEDMD, MIM\# 310300) (Bione, et al., 1994). EMD encodes emerin, a small integral membrane protein located at the inner nuclear membrane and a member of the LEM domain proteins (Wagner and Krohne, 2007). Mutations in the LMNA gene (1q21.3, MIM\# 150330), encoding the A-type lamins - lamin A and C by alternative splicing (Figure 1A), have been found in patients with autosomal dominant (EDMD2, MIM\# 181350) (Bonne, et al., 1999) and autosomal recessive (EDMD3, MIM\# 604929) (Raffaele Di Barletta, et al., 2000) forms of EDMD. LMNA mutations are also associated with a congenital muscular dystrophy termed LMNA-related congenital muscular dystrophy (L-CMD, MIM\# 613205) (Quijano-Roy, et al., 2008). Lamins A and C are type V intermediate filament proteins, and together with B-type lamins, are major components of the nuclear lamina: a proteinaceous meshwork underlying the inner nuclear membrane thought to provide a structural framework for the nuclear envelope and an anchoring site at the nuclear periphery for interphase chromosomes. Recently, it has been shown that mutations in the FHL1 gene (Xq27.2, MIM\# 300163) are also associated with EDMD (Gueneau, et al., 2009). FHL1 encodes a LIM domain protein 
containing 2 zinc fingers in tandem, which has been implicated in sarcomere assembly (Gueneau, et al., 2009; McGrath, et al., 2006).

Emerin and lamin A/C are thought to have a close functional relationship, even though the phenotypes caused by EMD and LMNA mutations are clinically different (Bonne, et al., 2003; Meune, et al., 2006). In fact, direct interaction between emerin and lamin A has been demonstrated by multiple experimental techniques (Clements, et al., 2000; Lee, et al., 2001) and emerin localization has been shown to be affected by mutant lamin A (Holt, et al., 2003). LMNA mutations have also been detected in patients with autosomal dominant limb-girdle muscular dystrophy with atrioventricular conduction disturbances (LGMD1B, MIM\# 159001) (Muchir, et al., 2000). While the clinical phenotype of LGMD1B overlaps with EDMD, there are differences, for example, LGMD1B is characterized by slowly progressive pelvic girdle weakness, with a sparing of the lower leg muscles. In addition, contractures and cardiac disturbances tend to occur later in life in LGMD1B, compared to EDMD patients (Muchir, et al., 2000).

In addition to EDMD, LGMD1B, L-CMD and isolated dilated cardiomyopathy and conduction-system disease (CMD1A, MIM\# 115200) (Fatkin, et al., 1999) that primarily affect striated muscle, 'laminopathies' also affect other tissues. Such laminopathies include Dunningan-type familial partial lipodystrophy (FPLD, MIM\# 151660) (Hegele, et al., 2000; Shackleton, et al., 2000; Speckman, et al., 2000), autosomal recessive Charcot-Marie-Tooth Disorder Type 2B1 (CMT2B1, MIM\# 605588) (De Sandre-Giovannoli, et al., 2002), mandibuloacral dysplasia (MAD, MIM\# 248370) (Novelli, et al., 2002; Shen, et al., 2003), Hutchinson-Gilford progeria syndrome (HGPS, MIM\# 176670) (De Sandre-Giovannoli, et al., 2003; Eriksson, et al., 2003), and autosomal dominant atypical Werner's syndrome 
(WRN, MIM\# 150330) (Chen, et al., 2003). In addition, both intra-familial and inter-familial variability of phenotypes associated with LMNA mutations is a common feature (Shen, et al., 2003; Simha, et al., 2003; Speckman, et al., 2000; Vytopil, et al., 2002).

A clear genotype-phenotype correlation has not been identified for most laminopathies, although HGPS tends to correlate with C-terminal splicing defects, while other conditions (i.e. MAD, WRN and CMT2B1) result from 'hot spot' missense mutations. For other laminopathies including EDMD, the pathogenic LMNA mutations are distributed throughout the gene (Scharner, et al., 2010). The LMNA gene contains 12 exons and encodes both lamin $\mathrm{A}$ and $\mathrm{C}$ by alternative splicing, both sharing the first 566 amino acids (Lin and Worman, 1993). In addition to their role in the nuclear lamina, lamins also interact with numerous integral proteins of the inner nuclear membrane and proteins of nuclear pore complexes (Schirmer and Foisner, 2007), orchestrating a number of cellular and molecular processes including nuclear envelope assembly, maintenance of nuclear architecture, DNA synthesis, chromatin organization, gene transcription, cell cycle progression, cell differentiation and migration and response to DNA damage (Broers, et al., 2006; Prokocimer, et al., 2009; Verstraeten, et al., 2007), processes that could be differentially affected by specific mutations.

This report describes novel and recurrent $L M N A$ mutations identified in 50 patients referred for clinical testing for a suspected diagnosis of EDMD or LGMD in the USA and Canada. This is also the first report of the distribution of $L M N A$ mutations from a large patient cohort from outside Europe, and augments the EDMD mutation database by $\sim 6 \%$. Importantly, amongst these were 15 novel pathogenic LMNA mutations that include eight missense mutations (p.R189P, p.F206L, p.S268P, p.S295P, p.E361K, p.G449D, p.L454P and 
p.W467R), three splice site mutations (c.IVS4+1G>A, c.IVS6-2A>G, c.IVS8+1G>A), one duplication/in frame insertion (p.R190dup), one deletion (p.Q355del) and two silent mutations (p.R119R and p.K270K). Examining 4 LMNA of our mutations further, we found that mutations located in various protein domains differentially affect basic nuclear characteristics including nuclear size, shape and protein distribution. Taken together, we provide clinical and in vitro data to confirm the complex pathogenicity associated with LMNA mutations, suggesting that genetic background is also a major player in the severity of the expressed phenotype of autosomal EDMD. 


\section{Material and Methods}

\section{Patients}

The 255 patients reported in this manuscript were referred to either the DNA Diagnostic Laboratory at Carolinas Medical Center (1996-2001) or the Molecular Diagnostics Laboratory at the University of Minnesota (2001-2003) from the United States of America and Canada for mutation analysis of the LMNA gene (GenBank Accession Number RefSeq NM_170707.2). The clinical diagnoses of patients referred for testing included muscular dystrophies of the EDMD, LGMD, congenital, Becker (BMD) and fascioscapulohumeral (FSHD) types, as well as spinal muscular atrophy (SMA). This study was approved by the Institutional Review Board at both Carolinas Medical Center and the University of Minnesota.

\section{DNA Isolation and Polymerase Chain Reaction}

DNA extracted from peripheral blood by either standard proteinase $\mathrm{K} /$ phenol-chloroform extraction procedures on a 341 Nucleic Acid Extractor (Perkin-Elmer, Norwalk, CT) or using a QIamp DNA Blood Mini Kit (Qiagen, Valencia, CA). Exons 1-12 of LMNA were amplified by PCR as previously described (Brown et al. 2001). Primers used for the PCR reaction are listed in table 1.

\section{Sequencing}

Amplimers were extracted from agarose gel using a Gel Extraction Kit (Qiagen, Valencia, CA) and each exon sequenced directly from both strands using the Prism Ready Reaction DyeDeoxy Terminator Cycle Sequencing Kit (Applied Biosystems, Foster City, CA) with analysis of sequenced products on either an ABI377 or ABI3100 Genetic Analyzer. 
Generated sequences were compared to the published EMD or LMNA gene sequence using the Sequence Navigator (Applied Biosystems, Foster City, CA) or Sequencher (Gene Codes Corporation, Ann Arbor, MI) software packages. Nucleotide numbering reflects cDNA numbering with +1 corresponding to the A of the ATG translation initiation codon in the reference sequence, according to journal guidelines (www.hgvs.org/mutnomen). The initiation codon is codon 1 .

\section{Retroviral expression vectors}

The retroviral (RV) backbone pMSCV-puro (Clontech, Mountain View, CA) was modified to replace the puromycin selection gene with eGFP, to create $p M S C V-I R E S-e G F P$, which served as the RV control vector (Zammit, et al., 2006). Wild type (Motsch, et al., 2005) and four mutant human lamin A pEGFP-C1 cDNAs (R25P, R249W, N456I and R541P) were sub-cloned into pMSCV-IRES-eGFP to generate control pMSCV-laminA-IRES-eGFP and pMSCV-laminA-R25P-IRES-eGFP, pMSCV-laminA-R249W-IRES-eGFP, pMSCV-laminAN456I-IRES-eGFP and pMSCV-laminA-R54IP-IRES-eGFP, producing either wildtype lamin A as a control, or mutant lamin A species, as a bicistronic message with eGFP (Figure 2C). Retroviral constructs, together with an ecotropic packaging plasmid, were transiently cotransfected into $293 \mathrm{~T}$ cells to produce non-replicating retrovirus and the supernatant harvested 48, 60 and 72 hours later.

\section{Cell Culture and Retroviral infection}

C2C12 mouse myoblast cells were grown and maintained in DMEM-Glutamax (Invitrogen, Paisley, UK) supplemented with $10 \%$ FBS (PAA, Somerset, UK) and $1 \%$ Penicillin/Streptomycin (Sigma, Dorset, UK). A total of 20,000 C2C12 cells were plated into one well of a 6-well plate and exposed to retroviral supernatant (diluted 1:5 in growth 
medium supplemented with $4 \mu \mathrm{g} / \mathrm{mL}$ polybrene) for at least 12 hours, before they were analyzed at least 24 hours later.

\section{Morphometric Analysis}

To quantify the morphological abnormalities of nuclei such as elongation or lobulation, we measured the perimeter and the area of at least 120 nuclei from 3 independent experiments and calculated the nuclear roundness or contour ratio $\left(4 \pi\right.$ area/circumference $\left.{ }^{2}\right)($ Goldman, et al., 2004). The contour ratio of a circle is 1 and the value gets smaller with an increased degree of lobulation. Micrographs of infected C2C12 cells stained for lamin B were analyzed using the NIH ImageJ software (http://rsbweb.nih.gov/ij/). To calculate the perimeter and area of the nuclei, they were outlined using the polygon selection tool and measured with ImageJ. A two-tailed Student's t-test was used to calculate the statistical significance of the result.

\section{Immunostaining}

Cells were fixed with $4 \%$ paraformaldehyde (PFA) for 10 minutes, permeabilized with $0.5 \%$ Triton X-100 in PBS for 10 minutes and blocked with 5\% normal goat serum and 5\% normal swine serum (or 5\% horse serum and 5\% normal swine serum when primary antibodies raised in goat were used) in PBS/ $0.025 \%$ Tween20 for 1 hour at room temperature. After incubation with primary antibody in 1\% serum (goat anti-lamin A C20 1:100, goat anti-lamin A/C N18 1:200, goat anti-lamin B (recognises all forms) M20 1:200 (Santa Cruz Biotechnology, Santa Cruz, CA); rabbit anti-emerin AP8 1:100 (Ellis, et al., 1998); rabbit anti-GFP 1:500 (Molecular Probes, Eugene, OR) and mouse anti-GFP 7.1\&13.1 1:100 (Roche, Mannheim, Germany)), the cells were washed and exposed to fluorescently coupled secondary antibodies (Alexa Fluor - Molecular Probes, Eugene, OR) at a concentration of 
1:500 and mounted in DAPI containing mounting medium. F-actin was stained by exposing the PFA-fixed cells to Alexa Fluor 633 conjugated phalloidin (Molecular Probes, Eugene, OR) (diluted 1:50 in PBS+0.025\% Tween20) for 30 minutes prior washing and mounting the slides with DAPI containing mounting medium.

\section{Fluorescence intensity measurement}

Representative nuclei stained for DAPI, lamin A and lamin B respectively were analyzed using the "Plot Profile" tool in ImageJ. The $\mathrm{x}$, y coordinates were imported in MS Excel to compile the histogram.

\section{Western Blot}

Harvested cells were re-suspended in suspension buffer $(100 \mathrm{mM} \mathrm{NaCl}, 10 \mathrm{mM}$ TrisHCl $\mathrm{pH} 7.5,1 \mathrm{mM}$ EDTA) supplemented with proteinase inhibitors and lysed in loading buffer (Laemmli, 1970). The protein concentration was determined with the Bio-Rad DC Protein Assay based on the Lowry method (Lowry, et al., 1951). Samples were immunoblotted with the following antibodies: goat anti-lamin A/C N18 1:1000 (Santa Cruz Biotechnology, Santa Cruz, CA), rabbit anti-GFP 1:2000 (Molecular Probes, Eugene, OR), mouse anti $\beta$-tubulin 1:1000 (DSHB, Iowa City, IA), and then probed with HRP-conjugated secondary antibodies $\left(\mathrm{ECL}^{\mathrm{TM}}\right.$ sheep anti mouse or rabbit 1:5000, GE Healthcare, Uppsala, Sweden; sheep anti goat SO84 1:5000, Abcam, Cambridge, UK) and developed using ECL from GE Healthcare. Band intensity was quantified using ImageJ. 


\section{Results}

\section{Clinical and genetic information on 50 patients}

This is the first report on the distribution of $L M N A$ mutations from a large patient cohort from the USA and Canada. Among the 255 referrals, 23 patients $(9.0 \%)$ were found to possess $E M D$ gene mutations (manuscript in preparation) and 61 individuals (23.9\%) were found to have $L M N A$ mutations. Clinical and genetic information on 11 of the patients with LMNA mutations has been published previously (Brown, et al., 2001). The mutations identified in the remaining 50 patients and their clinical information are presented in Tables 2 and 3.

Amongst the 50 individuals found to carry a $L M N A$ mutation, 37 different mutations (in 36 patients) were detected, scattered throughout the gene (Figure 1A and Table 2 and 3). The majority of LMNA mutations identified here are missense mutations $(27 / 37 ; 73.0 \%)$, with an additional 2 mutations being small in-frame insertions or deletions $(2 / 37 ; 5.4 \%)$. Seven mutations were found to be deleterious mutations at conserved donor or acceptor splice site sequences $(5 / 37 ; 13.5 \%)$ or silent mutations $(2 / 37 ; 5.4 \%)$. The final mutation in patient 2974 was the only frame shift mutation, presumably encoding both truncated lamin A and lamin C protein species $(1 / 37 ; 2.7 \%)$. This patient had a predominantly cardiac phenotype with only mild skeletal muscle weakness developing at age 50. These results are consistent with the phenotypes of other patients found to possess truncating mutations (Benedetti, et al., 2007). The most common previously reported $L M N A$ mutation, c.1357C $>\mathrm{T}$ (p.R453W), was also the most frequent in our study group, being found in $6(12.0 \%)$ of the patients. Two mutations were found to be confined to the lamin A protein, p.G602S and p.R644C, suggesting that alterations in the far C-terminus of the lamin A protein alone is sufficient to cause EDMD2. 
A few of the patients with p.R249W and p.E358K and p.N39S presented at $<1-2$ years old (Table 2), which is below the average onset age for a severe EDMD2 case (32 months). Interestingly, these mutations have recently been reported to be associated with the congenital muscular dystrophy L-CMD, where the age of onset is from birth to 1 year.

Five patients $(33,7975,1412,6388$ and 2660) had mutations located in non-coding regions at the exon-intron or intron-exon junctions affecting the universally conserved GT and AG di-nucleotides. Therefore, these mutations likely affect pre-mRNA splicing although RNA analysis was not performed. These patients with intronic splice site mutations presented with an EDMD phenotype (Table 2). A further three patients (91, 778 and 2018) had two silent mutations located on either the first or last nucleotides of an exon, which could also modify splicing.

Of the 45 patients for whom a family history was available, there was an approximately even split between cases that appeared to be familial in origin (21/45 [46.7\%]) compared to cases that appeared to be sporadic (24/45 [53.3\%]). Indeed, for our commonest mutation for which we have information (p.R453W), 2 cases were familial and 3 cases were sporadic. DNA analysis was only performed on the family members of 3 cases classed as sporadic (patients 6537,3734 , and 778), which confirmed the de novo origin of mutations in these individuals. It is possible of course, that apparently sporadic cases may have relatives who are currently asymptomatic gene mutation carriers.

\section{Novel pathogenic $L M N A$ mutations}

Of these 37 LMNA mutations, 15 are novel pathogenic LMNA mutations (highlighted in red in Figure $1 \mathrm{~A}$ and $\mathrm{B}$ and Table 2 and 3), not previously published or listed in any of the 
following databases: The Universal Mutation Database (UMD) (http://www.umd.be/), Human Intermediate Filament Database (http://www.interfil.org/) (Szeverenyi, et al., 2006) and the Leiden Open Variation Database (LOVD) (http://www.dmd.nl/). This augments the number of $L M N A$ mutations known to cause EDMD by $16.5 \%$, equating to an increase of 5.9\% in the total known LMNA mutations. These 15 mutations include eight missense mutations (p.R189P, p.F206L, p.S268P, p.S295P, p.E361K, p.G449D, p.L454P and p.W467R), three splice site mutations (c.IVS4+1G>A, c.IVS6-2A>G, c.IVS8+1G>A), one duplication/in frame insertion (p.R190dup), one deletion (p.Q355del) and two silent mutations (p.R119R and p.K270K). The majority of patients carrying novel mutations (13/15) show symptoms associated with EDMD, while patient 2018 carrying the silent mutation c.810G >A (p.K270K), was initially diagnosed with BMD, prior to screening for LMNA mutations. Patient 91 carrying the silent mutation c.357C >T (p.R119R) presented with an LGMD1B phenotype with cardiac involvement. Of the 12 mutations located in the coding region of $L M N A$, four are in coil 1B, five are in coil 2 of the central rod domain, and the remaining three are located on conserved residues in the Ig-like fold of the tail of the lamin A/C protein (Figure 1A).

The LMNA gene is well conserved with $33 \%$ homology of the coding region between $D$. melanogaster and Homo sapiens. The majority of our novel missense mutations and one insertion (7/10) affect residues conserved between species from C. elegans to Homo sapiens, whilst the remaining two missense mutations and one deletion (p.R189P, p.S268P and p.Q355del) are all located in the central rod domain, and affect residues that are less conserved between species (Figure 1B).

\section{Effects of lamin A mutants on myogenic cells}


Having described pathogenic $L M N A$ mutations in patients, we next sought to gain insight into the effects of several mutant human lamin A species on myogenic cells. We chose four mutations from this (p.R249W and p.R541P) and our previous study (p.R25P and p.N456I) (Brown, et al., 2001) that span the LMNA gene and affect different domains of the protein. The majority of pathogenic lamin A mutations are dominant, with usually only one allele being affected in patients. This suggests that in cases that are not caused by haploinsufficiency, the amount of mutated protein that is necessary to create a phenotype is relatively small. Importantly, patient myoblasts are not readily available and a commonly used DNA delivery method is cell transfection, which results in dramatic over-expression (up to 25 fold) of mutant lamin A (Bechert, et al., 2003).

Retroviral infection is efficient in mouse $\mathrm{C} 2 \mathrm{C} 12$ myogenic cells with an infection rate of $>98 \%$ routinely obtained (data not shown). Retroviral-mediated constitutive expression of wild-type lamin A clearly shows the co-expression of lamin A and eGFP, with cells with higher levels of eGFP generally also expressing higher levels of lamin A (Figure 2A). In addition to efficiently targeting $>98 \%$ cells, retroviral-mediated constitutive expression also has the advantage that the levels of exogenous proteins are generally only moderately elevated compared to endogenous proteins. Western blot analysis confirmed increased levels of exogenous wild type and mutant lamin A was only on average 1.3-1.7 fold higher than controls (Figure 2B) resembling a more physiological condition. Endogenous expression level of lamin C was not affected (Figure 2B).

\section{The presence of lamin A-R25P and lamin A-R249W results in abnormal nuclear morphology}


We observed large differences in nuclear size depending on the lamin variant expressed. While a small increase in the nuclear cross-sectional area was observed in cells treated with the RV control, the average nuclear size was further significantly increased in the presence of lamin A-R25P (29\% increase) and lamin A-R249W (34\% increase) compared to lamin Awild type infected cells (Figure 2D). Constitutive expression of lamin A-wild type did not have an effect on nuclear size. The dramatic increase in nuclear size coincides with changes in nuclear morphology. Normal ovoid nuclear morphology was observed when cells were

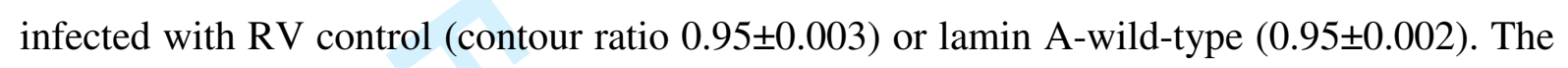
presence of either lamin A-R25P or lamin A-R249W however, resulted in abnormal nuclear morphology with simple or multiple lobules of the nuclear envelope. The contour ratio was

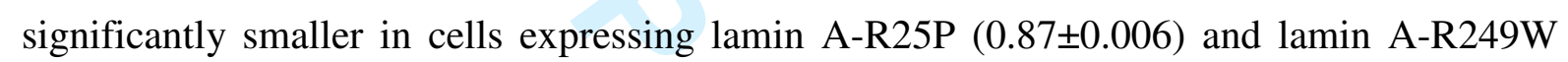
$(0.85 \pm 0.007)$, reflecting these nuclear distortions (Figure $2 \mathrm{E}$ ). Changes in both nuclear size and contour ratio occurred concomitantly. This effect was mutation specific however, since the presence of lamin A-N456I or lamin A-R541P did not alter nuclear size or shape.

\section{Mutant lamin A protein species are mislocalised in the nucleus}

Abnormalities in mutant lamin A protein distribution were also observed (Figure 3 and 4AC). Although all the mutant lamin A proteins were present to some degree at the nuclear periphery, there was frequent disorganisation of the lattice, with evidence of lamin A capping, particularly in lamin A-R25P and lamin A-R249W-expressing nuclei (lamin A mislocalization is shown by arrows in Figure 3). There were also more lamin A-positive nuclear speckles present, with a greater size distribution compared with cells expressing lamin A-wild type. Prominent lamin A speckles distributed throughout the nucleus were particularly evident in many cells expressing the lamin A-N456I and lamin A-R541P mutant proteins, (lamin A-N456I, 25.9\% $\pm 4.0 \%$; lamin A-R541P, 9.0\% $03.5 \%$ ) than with the other 
mutants (Figure 4A and C). Lamin A speckles observed in lamin A-N456I infected cells were generally larger in size compared to those observed in lamin A-R541P infected cells (Figure 4A). When the fluorescence intensity of lamin A together with that of DAPI was plotted on a histogram, lamin A-positive foci did not co-stain with the chromatin (Figure 4B). Nuclear lamin A foci were not analyzed in cells infected with RV control because the fixation protocol used to preserve cellular morphology resulted in endogenous mouse lamin A being weakly detected (Figure 3), compared to the robust immunostaining to the human lamin A species encoded by RVs.

\section{Endogenous lamin B mis-localization in the presence of lamin A-R25P and R249W}

To investigate whether other endogenous nuclear envelope components were mislocalised in the presence of the mutant lamin A proteins, we analyzed the expression of several components of the nuclear envelope by immunocytochemistry (Figures 3 and 4D-F). Lamin A and C directly bind emerin in vitro (Vaughan, et al., 2001) and have been shown to colocalize with mutant lamin A (Ostlund, et al., 2001). We therefore determined if the expression of our constructs had an effect on emerin localization, and if lamin A-N456I in particular, could cause nuclear foci that strongly immunostain for emerin. However, none of the lamin A mutants induced nuclear foci that contained emerin, confirming previous descriptions (Capanni, et al., 2003; Muchir, et al., 2004) (Figure 3). F-actin staining by standard immunofluorescence microscopy appeared normal, except in cells expressing the p.R25P mutation, where fewer stress fibres were observed (Figure 3).

The localization of lamin B however was changed by the expression of two mutant lamins. In nuclei of cells expressing lamin A-R25P and lamin A-R249W, B-type lamins were lost from one or more poles in some cells (Figure. 3, arrowed and Figure 4D), which was particularly 
severe with the p.R249W mutant. The DAPI staining pattern implies the nuclei remain intact, but the redistribution of lamin B is suggestive of nuclear membrane herniation. Figure 4D shows a detailed micrograph of lamin B stained cells infected with either lamin A-wild type, lamin A-R25P or lamin A-R249W. Fluorescent intensity profiles of DAPI and B-type lamin staining across a central axis of the nuclei were calculated (Figure 4E). Whereas the signal for lamin B in cells expressing lamin A-wild type (shown by the histogram) remained constant across the nucleus, in the presence of lamin A-R249W, where the central axis bisects one of the poles, the fluorescence intensity gradually reduced to background levels as the pole was approached. Nuclei of cells infected with lamin A-R25P showed an intermediate phenotype between lamin A-wild type and lamin A-R249W. While less than $10 \%$ of nuclei infected with lamin A-wild type, lamin A-N456I and lamin A-R541P were affected, the number of nuclei with a polar loss of lamin B was significantly higher in presence of lamin A-R25P (19.6\% $\pm 2.7 \%)$ and especially lamin A-R249W (32.7\% $\pm 3.3 \%)$, with cells containing the R249W mutation being the most severely affected (Figure 4F). 


\section{Discussion}

In this study we report 16 patients with novel, and 34 patients with recurring LMNA mutations, increasing the known LMNA mutation database by $\sim 5.9 \%$ (The Universal Mutation Database (UMD)). Since laminopathies are rare diseases, this significant increase in patient data will hopefully aid genotype/phenotype correlations.

Variable expressivity of the EDMD phenotype is noted in many families illustrating the importance of the genetic background for clinical presentation. One example of highly variable expressivity in EDMD2 is demonstrated by the family of patient 7309 , found to be heterozygous for the common p.R453W lamin A/C mutation. The proband was initially diagnosed with a mild form of LGMD1B at age 6, and at age 26, he had mild proximal muscle weakness, contractures and cardiac involvement. The probands father died of heart failure at age 61, at which time he had neck and elbow contractures, but minimal, if any, muscle weakness. The proband's paternal grandmother was not considered to be affected with EDMD until an autopsy performed at age 88 revealed a skeletal muscle myopathy consistent with this disorder, but a cardiac muscle biopsy exhibited no significant pathology. Another example of the phenomenon of variable expressivity is demonstrated by patient 33, who was found to be heterozygous for an intron 4 splice junction mutation. Whilst both patient 33 and his sister were known to be affected with EDMD2 upon referral for genetic testing, neither of their parents showed any clinical signs of this disorder. Molecular testing indicated that their father carried the splice junction mutation and shortly after receiving this information, presented with cardiac arrhythmia. 
Two patients were found to have a missense mutation within codon 541. Patient 198, with a predicted p.R541P mutation within lamin A/C was diagnosed with LGMD1B. She has two affected children, a daughter diagnosed with mild LGMD1B and a son with a severe form of EDMD. A p.R541S mutation was detected in patient 2743 who required a heart transplant at age 13 due to severe DCM. Other members of this family possessing the p.R541S mutation were diagnosed with either dilated cardiomyopathy or LGMD1B, while female mutation carriers had an unusual habitus due to loss of adipose tissue.

We previously reported patient 1325 who is heterozygous for both p.E358K and p.R624H mutations (Brown, et al., 2001). We hypothesized that the compound heterozygous mutations found in this patient may account for her particularly severe phenotype, with the lamin Aspecific mutation being either recessive or dominant with incomplete penetrance, as it was detected in her clinically unaffected father. Of note, three other patients in this study were found to be heterozygous for just the p.E358K mutation, and all appear to be severely affected with EDMD, making the role of the second, lamin A-specific mutation, in patient 1325 unclear. In this study, 2 compound heterozygous patients were found, both presenting with an early onset phenotype (marked by \# in table 2). Patient 6388, with a severe form of EDMD, was compound heterozygous for c.IVS-1G>T and p.D461Y, two mutations that have been described before in a patient with early onset EDMD (Bakay, et al., 2006). A second severely affected patient (patient 3) was also found to be a compound heterozygote carrying p.R249W and p.R644C mutations. Interestingly, our study population included patients carrying each of these sequence alterations individually, with patient 8281 being heterozygous for the p.R249W alteration and patient 51 being heterozygous for the lamin Aspecific p.R644C mutation. As the two latter patients with single mutations are affected with early age-of-onset disease, both of these mutations appear to act in a dominant fashion. This 
paradox suggests further studies are required to determine the true reason behind modifying effects, if any, of compound heterozygosity on clinical phenotype.

In 2008, Quijano-Roy et al. reported a new form of congenital muscular dystrophy associated with eleven different mutations in the LMNA gene (Quijano-Roy, et al., 2008). Notably, affected patients presented with muscle weakness between birth and the first year of life (rather than at an average age of 32 months as seen for EDMD2). L-CMD patients additionally display a dropped head, also not observed in EDMD2. The muscle weakness in L-CMD expresses as selective axial weakness and wasting of the cervicoaxial muscles with a predominantly proximal upper and distal lower limb involvement. Of 50 patients reported in our study, 14 (marked by $\uparrow$ in table 2) associated with 11 different singular mutations originating from familial and sporadic origin, expressed a severe EDMD-like phenotype characterised by an onset of $<3$ years of age or early cardiac involvement. Three mutations (p.N39S, p.R249W and p.E358K) with an early onset were also reported to cause L-CMD (Quijano-Roy, et al., 2008). Three further mutations described here (c.IVS4+1G>A, p.G449D and p.W467R) causing early onset EDMD are novel. The remaining five mutations (p.R249Q, p.S303P, p.R527P, p.T528R and p.R644C) have been previously described as causing EDMD (Benedetti, et al., 2007; Bonne, et al., 1999; Bonne, et al., 2000; Boriani, et al., 2003; Brown, et al., 2001; Fokkema, et al., 2005; Muchir, et al., 2004; Onishi, et al., 2002; Raffaele Di Barletta, et al., 2000; van der Kooi, et al., 2002; Vytopil, et al., 2003) with R644C causing a large variety of phenotypes including EDMD (Brown, et al., 2001; Csoka, et al., 2004; Mercuri, et al., 2005; Rankin, et al., 2008). We conclude that additional mechanisms must contribute to the disease severity at presentation such as modifier genes or digenism. Patients with mutations in both $E M D$ and $L M N A$ genes present with a more severe 
phenotype (Ben Yaou, et al., 2007), but all our patients were also screened for EMD mutations and found to be negative.

Taking the entire lamin A protein, approximately $50 \%$ of all pathogenic mutations affect residues that are conserved from man to $C$. elegans. Although mutations in the conserved residues are more likely to cause a phenotype, to date no clear genotype-phenotype correlation has been established. Six of eight novel amino acid substitutions described in this report affect highly conserved residues of the lamin A protein. Two affected residues reported to be pathogenic (p.R189 and p.S268) are located in the central rod domain of lamin A and are not conserved in evolution. Interestingly, both non-conserved residues are mutated to a proline and located adjacent to pathogenic residues. These are p.R190, associated with DCM when mutated to Trp or Gln (Perrot, et al., 2009; Sylvius, et al., 2005), and p.Y267, associated with EDMD and DCM when mutated to His or Cys (Carboni, et al., 2008; Vytopil, et al., 2003). Proline is not found in the centre of a straight alpha-helix, due to its helix breaking attributes (Richardson and Richardson, 1988). Interestingly, 9/30 (30\%) of all pathogenic, non-conserved residues in the central rod domain, are substituted to a proline. Eight of these cause either EDMD or DCM while one (p.A57P) has been reported to cause WRN (Chen, et al., 2003). Our data therefore confirms the assumption that the introduction of a proline is more likely to be pathogenic irrespective of amino acid conservation.

Eight patients were found to have mutations located on the exon-intron or intron-exon junctions, suggesting they may affect pre-mRNA splicing. In five $(33,7975,1412,6388$ and 2660), the universally conserved GT and AG di-nucleotides are affected. The majority of intronic splice site mutations published so far are associated with DCM or LGMD1B (Chrestian, et al., 2008; Muchir, et al., 2000; Otomo, et al., 2005) while others have been 
shown to result in EDMD (Bakay, et al., 2006). In our study however, all patients with intronic splice site mutations presented with an EDMD phenotype (Table 2). We also had three patients with mutations located on either the first nucleotide of exon 2 or the last nucleotide of exon 4. Patient 2018, who presented with DCM, and patient 778, who presented with an EDMD phenotype with cardiac involvement, both had the last nucleotide of exon 4 mutated to an A (c.810G >A; p.K270K). In patient 91, who presented with an LGMD phenotype with cardiac involvement, the first nucleotide in exon 2 is mutated to a $\mathrm{T}$ (c.357C $>$ T; p.R119R) (Figure 1A). Such mutation-types are very rare mutational events and only one other such mutation has been described so far in the LMNA gene. It is located on the last nucleotide of exon 2 (c.513G $>\mathrm{A} ; \mathrm{p} . \mathrm{K} 171 \mathrm{~K})$ and was found in four patients diagnosed with LGMD1B (Todorova, et al., 2003). mRNA analysis on these patients showed that this results in a partial skipping of the canonical 5' splice site in intron 2 and the alternative use of a cryptic GT donor site within intron 2 leading to an insertion of 15 additional amino acids between exon 2 and 3 (Todorova, et al., 2003).

Cells isolated from patients with $L M N A$ mutations, or cells over-expressing mutant lamin A, often display aberrant localization of nuclear envelope proteins and changes in nuclear morphology. In our study, we observe both phenomena: constitutive lamin A-R25P and lamin A-R249W expression caused severe changes in nuclear shape and size, while lamin AN456I and lamin A-R541P resulted in nuclear lamin A-positive foci. Nuclear foci staining for lamin A are frequently described when over-expressing mutant and lamin A-wild type in vitro (Bechert, et al., 2003; Holt, et al., 2001; Ostlund, et al., 2001). In contrast, such foci are not very common in primary cells isolated from patients with $L M N A$ mutations (Emerson, et al., 2009; Markiewicz, et al., 2002; Muchir, et al., 2004; Taimen, et al., 2009; Vigouroux, et al., 2001; Zhang, et al., 2007), suggesting that lamin A-positive foci formation can be 
attributed to lamin A over-expression. Patient fibroblasts that do show lamin A-positive foci usually carry FPLD but also EDMD causing mutations in the Ig-fold domain (Capanni, et al., 2003; Muchir, et al., 2004). We see similar effects using mouse C2C12 myogenic cells. Cells expressing lamin A-R25P and lamin A-R249W do not form nuclear foci staining for lamin A. However, constitutive expression of the lamin A variants with a mutation in the Ig-like fold (lamin A-N456I) and adjacent to the Ig-like fold (lamin A-R41P) induces lamin A foci formation in $25 \%$ and $10 \%$ of all infected nuclei respectively. Although nuclear foci appear to be smaller in cells infected with lamin A-R541P, these results may suggest that the molecular mechanism inducing these foci and perhaps the underlying disease mechanism, is similar for the two mutations in the tail domain of lamin A analyzed in this study.

In contrast, constitutive lamin A-R25P and lamin A-R249W expression in mouse myogenic cells caused severe changes in nuclear shape and size. Nuclear blebbing is a type of nuclear distortion commonly found in progeria and other laminopathies (Eriksson, et al., 2003; Goldman, et al., 2004; Jacob and Garg, 2006; Taimen, et al., 2009). Khatau et al. report that the nuclear morphology can be regulated by a perinuclear actin cap which is disrupted in cells from Imna $^{-/-}$and Imna $a^{\mathrm{L} 530 \mathrm{P} / \mathrm{L} 530 \mathrm{P}}$ mice (Khatau, et al., 2009). To test if the abnormal nuclear morphology we observed was associated with a misarranged actin-cytoskeleton, we stained infected C2C12 cells for F-actin. However, while there were perturbed F-actin stress fibres with lamin A-R25P, as has been described previously for other mutations in patient fibroblasts (Emerson, et al., 2009), confocal imaging did not reveal differences in the perinuclear actin cap associated with this, or any of our other mutant lamin A-species (data not shown). This suggests that there might be other factors involved in nuclear deformation in this case. One possibility of nuclear deformation is a misregulation of nesprin or other members of the LINC complex which physically connects the nuclear lamin with the 
cytoskeleton (Razafsky and Hodzic, 2009). The expression pattern of these interaction partners will be the subject of future investigations.

Interestingly, aberrant nuclear morphology in both mutants (lamin A-R25P and lamin A$\mathrm{R} 249 \mathrm{~W}$ ) is accompanied by a polar loss of lamin B expression in approximately $20-30 \%$ of nuclei. The same phenomenon has been observed by others in cells from HGPS patients with the p.E145K mutation (Taimen, et al., 2009) and in fibroblasts isolated from FPLD patients (Vigouroux, et al., 2001). Mouse embryonic fibroblasts from mouse embryos homozygous for a truncated, non-functional form of lamin B1 show severely misshaped nuclei too, suggesting that the loss of lamin B1 is a causative event for the observed nuclear lobulation (Vergnes, et al., 2004). How mutated lamin A affects lamin B localization is unclear and if a correction of lamin $\mathrm{B}$ expression can restore a normal nuclear morphology remains to be determined. It would also be very interesting to see if there are any LMNA single nucleotide polymorphisms (SNPs) that can affect lamin B localization and nuclear morphology.

Generally, patient fibroblasts with mutations associated with severe forms of laminopathies such as MAD (p.L59R, p.R527C, p.R527H) (Agarwal, et al., 2008; Nguyen, et al., 2007; Novelli, et al., 2002), WRN (p.R133L, p.L140R) (Caux, et al., 2003; Chen, et al., 2003) and FPLD (p.R439C) (Verstraeten, et al., 2009) all show the most profound changes in nuclear morphology. Taimen et al. have shown that nuclei of dermal fibroblast isolated from HGPS patients with the lamin A-E145K mutation show drastic changes in morphology and are severely lobulated (Taimen, et al., 2009). It has been suggested that the underlying mechanism of the pathogenicity of HGPS causing lamin A-E145K is a disrupted filament formation (Taimen, et al., 2009). However, mutant lamin A variants that caused an effect on nuclear morphology in our study result in either typical EDMD2 (lamin A-R25P) or an early 
onset/L-CMD phenotype (lamin A-R249W), but whether they affect filament formation to differing degrees is unknown.

A-type lamins are expressed in mouse satellite cells: the resident stem cells of skeletal muscle (Gnocchi, et al., 2009). Therefore perturbed lamin function does not only affect the myonuclei of muscle fibres, but could also compromise satellite cell-mediated muscle maintenance and repair. A disrupted nuclear morphology is likely to affect basic cellular processes, such as proliferation and differentiation of myoblasts (Gnocchi, et al., 2008). It is generally accepted that mutations in lamin A can affect cell cycle kinetics (Emerson, et al., 2009; Johnson, et al., 2004). Fibroblasts from HGPS patients demonstrate a decreased cell growth rate (Goldman, et al., 2004) and fibroblasts isolated from EDMD but not DCM patients have been shown to have an increase in cell proliferation (Emerson, et al., 2009). However, it has also been reported that cell cycle progression is dependent on nuclear size (Roca-Cusachs, et al., 2008; Yen and Pardee, 1979). It is therefore likely that cells expressing lamin A-R25P and lamin A-R249W show altered cell cycle progression and proliferation.

In conclusion, we describe 15 novel $L M N A$ mutations that underlie a striated muscle phenotype, increasing the mutation spectrum by $\sim 6 \%$. These will contribute towards formulating more accurate genotype-phenotype correlations in the laminopathies. Our analysis of $4 L M N A$ mutations shows that those located in the central rod domain perturb lamin B polarization and nuclear morphology, whilst mutations in the Ig-like fold domain increase lamin A-positive nuclear foci. We conclude that although the molecular mechanisms underlying the LMNA-generated pathogenic cascade in a particular tissue, with respect to intrinsic cellular processes such as cell cycle and cell signalling etc., may be similar for a given laminopathy, the disease penetrance and clinical variability within a phenotype may 
arise from the combined contribution of genetic background, digenism and environmental factors.

\section{Acknowledgements}

This work was supported by grant No. A6356678101 from the Muscular Dystrophy Association, awarded to JAE and CAB. JS was partially funded by the MYORES Network of Excellence (contract 511978) from the European Commission 6th Framework Programme, VFG was funded by The Medical Research Council (grant G0700307). The laboratory of PSZ is also supported by The Muscular Dystrophy Campaign, the Association of International Cancer Research, Association Française contre les Myopathies, The Wellcome Trust and OPTISTEM (contract 223098), through the European Union 7th Framework Programme. 


\section{References}

Agarwal AK, Kazachkova I, Ten S, Garg A. 2008. Severe mandibuloacral dysplasiaassociated lipodystrophy and progeria in a young girl with a novel homozygous Arg527Cys LMNA mutation. J Clin Endocrinol Metab 93(12):4617-23.

Arbustini EA, Pasotti M, Pilotto A, Repetto A, Grasso M, Diegoli M. 2005. Gene symbol: CMD1A. Disease: Dilated cardiomyopathy associated with conduction system disease. Hum Genet 117(2-3):295.

Bakay M, Wang Z, Melcon G, Schiltz L, Xuan J, Zhao P, Sartorelli V, Seo J, Pegoraro E, Angelini $C$ and others. 2006. Nuclear envelope dystrophies show a transcriptional fingerprint suggesting disruption of Rb-MyoD pathways in muscle regeneration. Brain 129(Pt 4):996-1013.

Bechert K, Lagos-Quintana M, Harborth J, Weber K, Osborn M. 2003. Effects of expressing lamin A mutant protein causing Emery-Dreifuss muscular dystrophy and familial partial lipodystrophy in HeLa cells. Exp Cell Res 286(1):75-86.

Ben Yaou R, Toutain A, Arimura T, Demay L, Massart C, Peccate C, Muchir A, Llense S, Deburgrave N, Leturcq F and others. 2007. Multitissular involvement in a family with LMNA and EMD mutations: Role of digenic mechanism? Neurology 68(22):1883-94.

Benedetti S, Menditto I, Degano M, Rodolico C, Merlini L, D'Amico A, Palmucci L, Berardinelli A, Pegoraro E, Trevisan CP and others. 2007. Phenotypic clustering of lamin A/C mutations in neuromuscular patients. Neurology 69(12):1285-92.

Bione S, Maestrini E, Rivella S, Mancini M, Regis S, Romeo G, Toniolo D. 1994. Identification of a novel X-linked gene responsible for Emery-Dreifuss muscular dystrophy. Nat Genet 8(4):323-7.

Bonne G, Di Barletta MR, Varnous S, Becane HM, Hammouda EH, Merlini L, Muntoni F, Greenberg CR, Gary F, Urtizberea JA and others. 1999. Mutations in the gene encoding lamin A/C cause autosomal dominant Emery-Dreifuss muscular dystrophy. Nat Genet 21(3):285-8.

Bonne G, Mercuri E, Muchir A, Urtizberea A, Becane HM, Recan D, Merlini L, Wehnert M, Boor R, Reuner U and others. 2000. Clinical and molecular genetic spectrum of autosomal dominant Emery-Dreifuss muscular dystrophy due to mutations of the lamin A/C gene. Ann Neurol 48(2):170-80.

Bonne G, Yaou RB, Beroud C, Boriani G, Brown S, de Visser M, Duboc D, Ellis J, Hausmanowa-Petrusewicz I, Lattanzi G and others. 2003. 108th ENMC International Workshop, 3rd Workshop of the MYO-CLUSTER project: EUROMEN, 7th International Emery-Dreifuss Muscular Dystrophy (EDMD) Workshop, 13-15 September 2002, Naarden, The Netherlands. Neuromuscul Disord 13(6):508-15. 
Capanni C, Cenni V, Mattioli E, Sabatelli P, Ognibene A, Columbaro M, Parnaik VK, Wehnert M, Maraldi NM, Squarzoni S and others. 2003. Failure of lamin A/C to functionally assemble in R482L mutated familial partial lipodystrophy fibroblasts: altered intermolecular interaction with emerin and implications for gene transcription. Exp Cell Res 291(1):122-34.

Carboni N, Mura M, Marrosu G, Cocco E, Ahmad M, Solla E, Mateddu A, Maioli MA, Marini S, Nissardi V and others. 2008. Muscle MRI findings in patients with an apparently exclusive cardiac phenotype due to a novel LMNA gene mutation. Neuromuscul Disord 18(4):291-8.

Caux F, Dubosclard E, Lascols O, Buendia B, Chazouilleres O, Cohen A, Courvalin JC, Laroche L, Capeau J, Vigouroux C and others. 2003. A new clinical condition linked to a novel mutation in lamins $\mathrm{A}$ and $\mathrm{C}$ with generalized lipoatrophy, insulin-resistant diabetes, disseminated leukomelanodermic papules, liver steatosis, and cardiomyopathy. J Clin Endocrinol Metab 88(3):1006-13.

Chen L, Lee L, Kudlow BA, Dos Santos HG, Sletvold O, Shafeghati Y, Botha EG, Garg A, Hanson NB, Martin GM and others. 2003. LMNA mutations in atypical Werner's syndrome. Lancet 362(9382):440-5.

Chrestian N, Valdmanis PN, Echahidi N, Brunet D, Bouchard JP, Gould P, Rouleau GA, Champagne J, Dupre N. 2008. A novel mutation in a large French-Canadian family with LGMD1B. Can J Neurol Sci 35(3):331-4.

Clements L, Manilal S, Love DR, Morris GE. 2000. Direct interaction between emerin and lamin A. Biochem Biophys Res Commun 267(3):709-14.

Colomer J, Iturriaga C, Bonne G, Schwartz K, Manilal S, Morris GE, Puche M, FernandezAlvarez E. 2002. Autosomal dominant Emery-Dreifuss muscular dystrophy: a new family with late diagnosis. Neuromuscul Disord 12(1):19-25. 
Csoka AB, Cao H, Sammak PJ, Constantinescu D, Schatten GP, Hegele RA. 2004. Novel lamin A/C gene (LMNA) mutations in atypical progeroid syndromes. J Med Genet 41(4):304-8.

De Sandre-Giovannoli A, Bernard R, Cau P, Navarro C, Amiel J, Boccaccio I, Lyonnet S, Stewart CL, Munnich A, Le Merrer M and others. 2003. Lamin a truncation in Hutchinson-Gilford progeria. Science 300(5628): 2055.

De Sandre-Giovannoli A, Chaouch M, Kozlov S, Vallat JM, Tazir M, Kassouri N, Szepetowski P, Hammadouche T, Vandenberghe A, Stewart CL and others. 2002. Homozygous defects in LMNA, encoding lamin A/C nuclear-envelope proteins, cause autosomal recessive axonal neuropathy in human (Charcot-Marie-Tooth disorder type 2) and mouse. Am J Hum Genet 70(3):726-36.

Ellis JA, Craxton M, Yates JR, Kendrick-Jones J. 1998. Aberrant intracellular targeting and cell cycle-dependent phosphorylation of emerin contribute to the Emery-Dreifuss muscular dystrophy phenotype. J Cell Sci 111 ( Pt 6):781-92.

Emerson LJ, Holt MR, Wheeler MA, Wehnert M, Parsons M, Ellis JA. 2009. Defects in cell spreading and ERK1/2 activation in fibroblasts with lamin A/C mutations. Biochim Biophys Acta 1792(8):810-21.

Emery AE. 1989. Emery-Dreifuss syndrome. J Med Genet 26(10):637-41.

Eriksson M, Brown WT, Gordon LB, Glynn MW, Singer J, Scott L, Erdos MR, Robbins CM, Moses TY, Berglund P and others. 2003. Recurrent de novo point mutations in lamin A cause Hutchinson-Gilford progeria syndrome. Nature 423(6937):293-8.

Fatkin D, MacRae C, Sasaki T, Wolff MR, Porcu M, Frenneaux M, Atherton J, Vidaillet HJ, Jr., Spudich S, De Girolami U and others. 1999. Missense mutations in the rod domain of the lamin A/C gene as causes of dilated cardiomyopathy and conductionsystem disease. N Engl J Med 341(23):1715-24.

Felice KJ, Schwartz RC, Brown CA, Leicher CR, Grunnet ML. 2000. Autosomal dominant Emery-Dreifuss dystrophy due to mutations in rod domain of the lamin A/C gene. Neurology 55(2):275-80.

Fidzianska A, Glinka Z. 2006. Rimmed vacuoles with beta-amyloid and tau protein deposits in the muscle of children with hereditary myopathy. Acta Neuropathol 112(2):185-93.

Fokkema IF, den Dunnen JT, Taschner PE. 2005. LOVD: easy creation of a locus-specific sequence variation database using an "LSDB-in-a-box" approach. Hum Mutat 26(2):63-8.

Genschel J, Bochow B, Kuepferling S, Ewert R, Hetzer R, Lochs H, Schmidt H. 2001. A R644C mutation within lamin A extends the mutations causing dilated cardiomyopathy. Hum Mutat 17(2):154. 
Hegele RA, Anderson CM, Cao H. 2000. Lamin A/C mutation in a woman and her two daughters with Dunnigan-type partial lipodystrophy and insulin resistance. Diabetes Care 23(2):258-9.

Holt I, Clements L, Manilal S, Brown SC, Morris GE. 2001. The R482Q lamin A/C mutation that causes lipodystrophy does not prevent nuclear targeting of lamin $\mathrm{A}$ in adipocytes or its interaction with emerin. Eur J Hum Genet 9(3):204-8.

Holt I, Ostlund C, Stewart CL, Man N, Worman HJ, Morris GE. 2003. Effect of pathogenic mis-sense mutations in lamin A on its interaction with emerin in vivo. J Cell Sci 116(Pt 14):3027-35.

Jacob KN, Garg A. 2006. Laminopathies: multisystem dystrophy syndromes. Mol Genet Metab 87(4):289-302.

Johnson BR, Nitta RT, Frock RL, Mounkes L, Barbie DA, Stewart CL, Harlow E, Kennedy BK. 2004. A-type lamins regulate retinoblastoma protein function by promoting subnuclear localization and preventing proteasomal degradation. Proc Natl Acad Sci U S A 101(26):9677-82.

Khatau SB, Hale CM, Stewart-Hutchinson PJ, Patel MS, Stewart CL, Searson PC, Hodzic D, Wirtz D. 2009. A perinuclear actin cap regulates nuclear shape. Proc Natl Acad Sci U S A 106(45):19017-22.

Ki CS, Hong JS, Jeong GY, Ahn KJ, Choi KM, Kim DK, Kim JW. 2002. Identification of lamin A/C ( LMNA) gene mutations in Korean patients with autosomal dominant 
Emery-Dreifuss muscular dystrophy and limb-girdle muscular dystrophy 1B. J Hum Genet 47(5):225-8.

Kichuk Chrisant MR, Drummond-Webb J, Hallowell S, Friedman NR. 2004. Cardiac transplantation in twins with autosomal dominant Emery-Dreifuss muscular dystrophy. J Heart Lung Transplant 23(4):496-8.

Laemmli UK. 1970. Cleavage of structural proteins during the assembly of the head of bacteriophage T4. Nature 227(5259):680-5.

Lee KK, Haraguchi T, Lee RS, Koujin T, Hiraoka Y, Wilson KL. 2001. Distinct functional domains in emerin bind lamin A and DNA-bridging protein BAF. J Cell Sci 114(Pt 24):4567-73.

Lin F, Worman HJ. 1993. Structural organization of the human gene encoding nuclear lamin A and nuclear lamin C. J Biol Chem 268(22):16321-6.

Lowry OH, Rosebrough NJ, Farr AL, Randall RJ. 1951. Protein measurement with the Folin phenol reagent. J Biol Chem 193(1):265-75.

Markiewicz E, Venables R, Mauricio Alvarez R, Quinlan R, Dorobek M, HausmanowaPetrucewicz I, Hutchison C. 2002. Increased solubility of lamins and redistribution of lamin C in X-linked Emery-Dreifuss muscular dystrophy fibroblasts. J Struct Biol 140(1-3):241-53.

McGrath MJ, Cottle DL, Nguyen MA, Dyson JM, Coghill ID, Robinson PA, Holdsworth M, Cowling BS, Hardeman EC, Mitchell CA and others. 2006. Four and a half LIM protein 1 binds myosin-binding protein $\mathrm{C}$ and regulates myosin filament formation and sarcomere assembly. J Biol Chem 281(11):7666-83.

Mercuri E, Brown SC, Nihoyannopoulos P, Poulton J, Kinali M, Richard P, Piercy RJ, Messina S, Sewry C, Burke MM and others. 2005. Extreme variability of skeletal and cardiac muscle involvement in patients with mutations in exon 11 of the lamin $\mathrm{A} / \mathrm{C}$ gene. Muscle Nerve 31(5):602-9.

Mercuri E, Poppe M, Quinlivan R, Messina S, Kinali M, Demay L, Bourke J, Richard P, Sewry C, Pike M and others. 2004. Extreme variability of phenotype in patients with an identical missense mutation in the lamin A/C gene: from congenital onset with severe phenotype to milder classic Emery-Dreifuss variant. Arch Neurol 61(5):690-4.

Meune C, Van Berlo JH, Anselme F, Bonne G, Pinto YM, Duboc D. 2006. Primary prevention of sudden death in patients with lamin A/C gene mutations. N Engl J Med 354(2):209-10.

Motsch I, Kaluarachchi M, Emerson LJ, Brown CA, Brown SC, Dabauvalle MC, Ellis JA. 2005. Lamins A and $\mathrm{C}$ are differentially dysfunctional in autosomal dominant EmeryDreifuss muscular dystrophy. Eur J Cell Biol 84(9):765-81. 


\section{Muntoni F, Bonne G, Goldfarb LG, Mercuri E, Piercy RJ, Burke M, Yaou RB, Richard P,} Recan D, Shatunov A and others. 2006. Disease severity in dominant Emery Dreifuss is increased by mutations in both emerin and desmin proteins. Brain 129(Pt 5):1260-8.

Nguyen D, Leistritz DF, Turner L, MacGregor D, Ohson K, Dancey P, Martin GM, Oshima J. 2007. Collagen expression in fibroblasts with a novel LMNA mutation. Biochem Biophys Res Commun 352(3):603-8.

Novelli G, Muchir A, Sangiuolo F, Helbling-Leclerc A, D'Apice MR, Massart C, Capon F, Sbraccia P, Federici M, Lauro R and others. 2002. Mandibuloacral dysplasia is caused by a mutation in LMNA-encoding lamin A/C. Am J Hum Genet 71(2):426-31.

Onishi Y, Higuchi J, Ogawa T, Namekawa A, Hayashi H, Odakura H, Goto K, Hayashi YK. 2002. [The first Japanese case of autosomal dominant Emery-Dreifuss muscular dystrophy with a novel mutation in the lamin A/C gene]. Rinsho Shinkeigaku 42(2):140-4.

Ostlund C, Bonne G, Schwartz K, Worman HJ. 2001. Properties of lamin A mutants found in Emery-Dreifuss muscular dystrophy, cardiomyopathy and Dunnigan-type partial lipodystrophy. J Cell Sci 114(Pt 24):4435-45.

Otomo J, Kure S, Shiba T, Karibe A, Shinozaki T, Yagi T, Naganuma H, Tezuka F, Miura M, Ito $\mathrm{M}$ and others. 2005. Electrophysiological and histopathological characteristics of progressive atrioventricular block accompanied by familial dilated cardiomyopathy caused by a novel mutation of lamin A/C gene. J Cardiovasc Electrophysiol 16(2):137-45.

Pasotti M, Klersy C, Pilotto A, Marziliano N, Rapezzi C, Serio A, Mannarino S, Gambarin F, Favalli V, Grasso M and others. 2008. Long-term outcome and risk stratification in dilated cardiolaminopathies. J Am Coll Cardiol 52(15):1250-60.

Perrot A, Hussein S, Ruppert V, Schmidt HH, Wehnert MS, Duong NT, Posch MG, Panek A, Dietz R, Kindermann I and others. 2009. Identification of mutational hot spots in LMNA encoding lamin $\mathrm{A} / \mathrm{C}$ in patients with familial dilated cardiomyopathy. Basic Res Cardiol 104(1):90-9. 
Prokocimer M, Davidovich M, Nissim-Rafinia M, Wiesel-Motiuk N, Bar D, Barkan R, Meshorer E, Gruenbaum Y. 2009. Nuclear lamins: key regulators of nuclear structure and activities. J Cell Mol Med.

Quijano-Roy S, Mbieleu B, Bonnemann CG, Jeannet PY, Colomer J, Clarke NF, Cuisset JM, Roper H, De Meirleir L, D'Amico A and others. 2008. De novo LMNA mutations cause a new form of congenital muscular dystrophy. Ann Neurol 64(2):177-86.

\section{Raffaele Di Barletta M, Ricci E, Galluzzi G, Tonali P, Mora M, Morandi L, Romorini A, Voit T, Orstavik KH, Merlini L and others. 2000. Different mutations in the LMNA gene cause autosomal dominant and autosomal recessive Emery-Dreifuss muscular dystrophy. Am J Hum Genet 66(4):1407-12.}

Rankin J, Auer-Grumbach M, Bagg W, Colclough K, Nguyen TD, Fenton-May J, Hattersley A, Hudson J, Jardine P, Josifova D and others. 2008. Extreme phenotypic diversity and nonpenetrance in families with the LMNA gene mutation R644C. Am J Med Genet A 146A(12):1530-42.

Razafsky D, Hodzic D. 2009. Bringing KASH under the SUN: the many faces of nucleocytoskeletal connections. J Cell Biol 186(4):461-72.

Richardson JS, Richardson DC. 1988. Amino acid preferences for specific locations at the ends of alpha helices. Science 240(4859):1648-52.

Roca-Cusachs P, Alcaraz J, Sunyer R, Samitier J, Farre R, Navajas D. 2008. Micropatterning of single endothelial cell shape reveals a tight coupling between nuclear volume in G1 and proliferation. Biophys J 94(12):4984-95.

Rudenskaya GE, Polyakov AV, Tverskaya SM, Zaklyazminskaya EV, Chukhrova AL, Groznova OE, Ginter EK. 2008. Laminopathies in Russian families. Clin Genet 74(2):127-33.

Scharner J, Gnocchi VF, Ellis JA, Zammit PS. 2010. Genotype-phenotype correlations in laminopathies: how does fate translate? Biochem Soc Trans 38(Pt 1):257-62.

Schirmer EC, Foisner R. 2007. Proteins that associate with lamins: many faces, many functions. Exp Cell Res 313(10):2167-79.

Shackleton S, Lloyd DJ, Jackson SN, Evans R, Niermeijer MF, Singh BM, Schmidt H, Brabant G, Kumar S, Durrington PN and others. 2000. LMNA, encoding lamin A/C, is mutated in partial lipodystrophy. Nat Genet 24(2):153-6.

Shen JJ, Brown CA, Lupski JR, Potocki L. 2003. Mandibuloacral dysplasia caused by homozygosity for the R527H mutation in lamin A/C. J Med Genet 40(11):854-7. 
Szeverenyi I, Ramamoorthy R, Teo ZW, Luan HF, Ma ZG, Ramachandran S. 2006. Largescale systematic study on stability of the Ds element and timing of transposition in rice. Plant Cell Physiol 47(1):84-95.

Taimen P, Pfleghaar K, Shimi T, Moller D, Ben-Harush K, Erdos MR, Adam SA, Herrmann H, Medalia O, Collins FS and others. 2009. A progeria mutation reveals functions for lamin A in nuclear assembly, architecture, and chromosome organization. Proc Natl Acad Sci U S A.

Todorova A, Halliger-Keller B, Walter MC, Dabauvalle MC, Lochmuller H, Muller CR. 2003. A synonymous codon change in the LMNA gene alters mRNA splicing and causes limb girdle muscular dystrophy type 1B. J Med Genet 40(10):e115.

van der Kooi AJ, Bonne G, Eymard B, Duboc D, Talim B, Van der Valk M, Reiss P, Richard P, Demay L, Merlini L and others. 2002. Lamin A/C mutations with lipodystrophy, cardiac abnormalities, and muscular dystrophy. Neurology 59(4):620-3.

van Tintelen JP, Hofstra RM, Katerberg H, Rossenbacker T, Wiesfeld AC, du Marchie Sarvaas GJ, Wilde AA, van Langen IM, Nannenberg EA, van der Kooi AJ and others. 2007. High yield of LMNA mutations in patients with dilated cardiomyopathy and/or conduction disease referred to cardiogenetics outpatient clinics. Am Heart J 154(6):1130-9.

Vaughan A, Alvarez-Reyes M, Bridger JM, Broers JL, Ramaekers FC, Wehnert M, Morris GE, Whitfield WGF, Hutchison CJ. 2001. Both emerin and lamin C depend on lamin A for localization at the nuclear envelope. J Cell Sci 114(Pt 14):2577-90.

Vergnes L, Peterfy M, Bergo MO, Young SG, Reue K. 2004. Lamin B1 is required for mouse development and nuclear integrity. Proc Natl Acad Sci U S A 101(28):10428-33.

Verstraeten VL, Broers JL, Ramaekers FC, van Steensel MA. 2007. The nuclear envelope, a key structure in cellular integrity and gene expression. Curr Med Chem 14(11):123148. 
Verstraeten VL, Caputo S, van Steensel MA, Duband-Goulet I, Zinn-Justin S, Kamps M, Kuijpers HJ, Ostlund C, Worman HJ, Briede JJ and others. 2009. The R439C mutation in LMNA causes lamin oligomerization and susceptibility to oxidative stress. J Cell Mol Med 13(5):959-71.

Vigouroux C, Auclair M, Dubosclard E, Pouchelet M, Capeau J, Courvalin JC, Buendia B. 2001. Nuclear envelope disorganization in fibroblasts from lipodystrophic patients with heterozygous R482Q/W mutations in the lamin A/C gene. J Cell Sci 114(Pt 24):4459-68.

Vytopil M, Benedetti S, Ricci E, Galluzzi G, Dello Russo A, Merlini L, Boriani G, Gallina M, Morandi L, Politano L and others. 2003. Mutation analysis of the lamin A/C gene (LMNA) among patients with different cardiomuscular phenotypes. J Med Genet 40(12):e132.

Vytopil M, Ricci E, Dello Russo A, Hanisch F, Neudecker S, Zierz S, Ricotti R, Demay L, Richard P, Wehnert M and others. 2002. Frequent low penetrance mutations in the Lamin A/C gene, causing Emery Dreifuss muscular dystrophy. Neuromuscul Disord 12(10):958-63.

Wagner N, Krohne G. 2007. LEM-Domain proteins: new insights into lamin-interacting proteins. Int Rev Cytol 261:1-46.

Yen A, Pardee AB. 1979. Role of nuclear size in cell growth initiation. Science 204(4399):1315-7.

Young J, Morbois-Trabut L, Couzinet B, Lascols O, Dion E, Bereziat V, Feve B, Richard I, Capeau J, Chanson $P$ and others. 2005. Type A insulin resistance syndrome revealing a novel lamin A mutation. Diabetes 54(6):1873-8.

Zammit PS, Relaix F, Nagata Y, Ruiz AP, Collins CA, Partridge TA, Beauchamp JR. 2006. Pax 7 and myogenic progression in skeletal muscle satellite cells. J Cell Sci 119(Pt 9):1824-32.

Zhang Q, Bethmann C, Worth NF, Davies JD, Wasner C, Feuer A, Ragnauth CD, Yi Q, Mellad JA, Warren DT and others. 2007. Nesprin-1 and -2 are involved in the pathogenesis of Emery Dreifuss muscular dystrophy and are critical for nuclear envelope integrity. Hum Mol Genet 16(23):2816-33. 


\section{Figure Legends}

\section{Figure 1. Schematic of the $L M N A$ gene and lamin A protein indicating mutations}

(A) Schematic of the LMNA gene and lamin A protein. Lamin A is encoded by exons 1-12 while lamin $\mathrm{C}$ terminates at exon 10 with 6 unique amino acids at its $\mathrm{C}$-terminal. The alternative splice site for lamin A is indicated. Sequence variations affecting splice donor or acceptor sites which lead to disease are shown for IVS 4, 6, 7 and 8. Missense mutations, insertions and deletions are indicated on the lamin A protein, where the head, central rod and tail domain (incorporating the nuclear localisation signal (NLS), and Ig-like fold) are indicated. Novel sequence variants are shown above the gene/protein (red) and mutations used for in vitro investigation are underlined (blue), while recurring mutations are shown beneath the gene/protein. Table 1 provides a detailed genetic description of the sequence variants. (B) Illustration of evolutionary conservation of residues associated with novel missense mutations, insertions and deletions located in the coding region of LMNA and those used in our in vitro analysis (blue/underlined). Sequences were obtained from the online databank swissprot (http://expasy.org/sprot/) and aligned with the online tool ClustalW2 (http://www.ebi.ac.uk/clustalw/). Partial sequence only, with // denoting non-consecutive sequence, * indicating identical residues in all aligned sequences; ':' showing conserved substitutions; and ' ' marking semi-conserved substitutions. If viewed in colour: residues with nonpolar side chains are indicated in red, acidic residues are shown in blue, basic residues shown in magenta and amino acids with uncharged polar side chains are indicated in green.

\section{Figure 2. Mutant lamin A species affect nuclear size and shape in myogenic cells}

(A) Proliferating mouse $\mathrm{C} 2 \mathrm{C} 12$ cells infected with control pMSCV-laminA-IRES-eGFP encoding wild type lamin A-IRES-eGFP and immunostained for eGFP and lamin A. Cells 
expressing high levels of GFP show a increased expression of lamin A-wild type

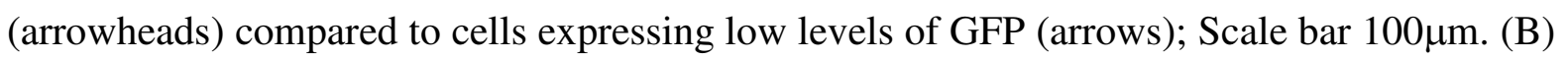
Western blot of uninfected $\mathrm{C} 2 \mathrm{C} 12$ cells and cells infected with pMSCV-IRES-eGFP (RV control), pMSCV-laminA-IRES-eGFP (Lamin A), pMSCV-laminA-R25P-IRES-eGFP (R25P), pMSCV-laminA-R249W-IRES-eGFP (R249W), pMSCV-laminA-N456I-IRES-eGFP (N456I) and pMSCV-laminA-R541P-IRES-eGFP (R541P). A representative blot probed for lamin $\mathrm{A} / \mathrm{C}(\mathrm{N} 19)$ is shown. The relative quantities of lamin A normalized to $\beta$-tubulin are shown below, and range from 1.5 - 1.7 fold endogenous lamin A levels in the RV control sample. The endogenous level of lamin C does not change with constitutive expression of wild-type lamin A or the mutant forms. (C) Schematic of the $p M S C V$-laminA-IRES-EGFP vector used in this study, indicating the 5' and 3' long terminal repeats (LTR), $\Psi$ packaging signal, the lamin A (wild type or mutant versions) and eGFP cDNAs, separated by an internal ribosome entry site (IRES). (D) Nuclear size (cross-sectional area) of cells with lamin A-R25P and lamin A-R249W increased by $29 \% \pm 3.3 \%$ and $34 \% \pm 4.5 \%$ respectively, compared to lamin Awild type infected cells. (E) The contour ratio was significantly decreased in nuclei of cells expressing lamin A-R25P $(0.87 \pm 0.006)$ and lamin A-R249W $(0.85 \pm 0.007)$, but not with the other two mutant lamin A species. Values represent the mean $\pm \mathrm{SEM} ; * p<0.05 ; * * p<0.01$ compared to lamin A-wild type infected cells.

Figure 3. Distribution of nuclear envelope-associated components in myogenic cells infected with mutant lamin A

Cells infected with $p M S C V$-IRES-eGFP (RV control), pMSCV-laminA-IRES-eGFP (Lamin A), pMSCV-laminA-R25P-IRES-eGFP (R25P), pMSCV-laminA-R249W-IRES-eGFP (R249W), pMSCV-laminA-N456I-IRES-eGFP (N456I) and pMSCV-laminA-R541P-IRESeGFP (R541P) were immunostained for nuclear envelope components (lamin A, lamin A/C, 
lamin B, emerin; Scale bar $=10 \mu \mathrm{m}$ ) and F-actin (red) (eGFP positive infected cells are indicated by arrowheads; Scale bar $=50 \mu \mathrm{m})$. A representative selection of nuclei and cells are shown. Lamin A-positive nuclear speckles and lamin A capping (arrows) as well as a loss of lamin B from nuclear poles was evident to varying degrees in a mutant-dependent fashion. The localization of emerin is normal in all instances.

\section{Figure 4. Nuclear abnormalities in myogenic cells infected with mutant lamin A}

(A) Prominent lamin A foci distributed throughout the nucleus were frequently observed in cells infected with lamin A-N456I and lamin A-R541P. Nuclei with representative lamin A foci are shown. Scale bar $=10 \mu \mathrm{m}$. (B) The fluorescence intensity of DAPI and lamin A along the central axis indicated by a dashed line is shown in the adjacent histogram. (C) Quantification of nuclei with prominent lamin A foci distributed throughout the nucleus. Values represent the mean $\pm \mathrm{SEM} ; * p<0.05$, ** $p<0.01$ compared to wild type lamin A infected cells (wild type). (D) Loss of lamin B expression from one or multiple poles is frequently observed in cells expressing lamin A-R25P and lamin A-R249W. Scale bar = $10 \mu \mathrm{m}$. (E) The fluorescence intensity of DAPI and lamin B along the central axis indicated by a dashed line is shown in the histogram. (F) Quantification of nuclei where a polar loss of lamin B expression was observed. Values represent the mean $\pm \mathrm{SEM} ; * p<0.05, * * p<0.01$ compared to wild type lamin A infected cells. 
Table 1: List of primers used for PCR and sequencing

\begin{tabular}{|c|c|c|}
\hline Exon & Primer Name & Sequence $\left(5^{\prime}-3^{\prime}\right)$ \\
\hline \multirow[t]{2}{*}{1} & $1 F^{* \dagger}$ & 5'-TCTCTGTCCTTCGACCCGAG-3' \\
\hline & $1 R^{*+}$ & 5'-ССТСТCСАСТCCCCGCCA-3' \\
\hline \multirow[t]{2}{*}{2} & $2 F^{*+}$ & 5'- ACAGACTCCTTCTCTTAAATCTAC-3' \\
\hline & $2 \mathrm{R}^{*+}$ & 5'-GTAGAAGAGTGAGTGTACATGTG-3' \\
\hline \multirow[t]{2}{*}{3} & $3 \mathrm{~F}^{*}+$ & 5'-ACCTCTCAGCTTCCTTCAAGTT-3' \\
\hline & $3 R^{+}$ & 5'-CTAGCCCAGCCCAAGTCTGT-3' \\
\hline \multirow[t]{2}{*}{4} & $4 \mathrm{~F}^{\dagger}$ & 5'-GCCTCCCAGGAACTAATTCTG- $3^{\prime}$ \\
\hline & $4 \mathrm{R}^{*+}$ & 5'-CGTGGGTAAGGGTAGGGCTG-3' \\
\hline \multirow[t]{2}{*}{5} & $5 \mathrm{~F}^{*+}$ & 5'-ATGCCCAACTCAGGCCTGTG-3' \\
\hline & $5 \mathrm{R}^{\dagger}$ & 5'-CGTTCCAGCCTGCATCCGG-3' \\
\hline \multirow[t]{2}{*}{6} & $6 \mathrm{~F}^{+}$ & 5'-ТCCCTCCTTCCCCATACTTAG-3' \\
\hline & $6 \mathrm{R}^{\dagger}$ & 5'-CCAGTTGCCGGGCCAGAG-3' \\
\hline \multirow[t]{2}{*}{7} & $7 \mathrm{~F}^{\dagger}$ & 5'-CCCCACTTGGTCTCCCTCTCC- $3^{\prime}$ \\
\hline & $7 R^{*+}$ & 5'-CCCTGATGCAGCTGTATCCCC-3' \\
\hline \multirow[t]{2}{*}{$8 / 9$} & $8 \mathrm{~F}^{*+}$ & 5'-CAAGATACACCCAAGAGCCTG-3' \\
\hline & 9Rt & 5'-CTCGTCCAGCAAGCAGCCAG-3' \\
\hline \multirow[t]{2}{*}{10} & $10 \mathrm{~F}^{+}$ & 5'-TCTTGTACAACCCTTCCCTGG-3' \\
\hline & $10 \mathrm{R}^{*+}$ & 5'-GGGTTCCCTGTTCAAGGTATA-3' \\
\hline \multirow[t]{2}{*}{11} & $11 \mathrm{~F}^{*+}$ & 5'-GTTGGGCCTGAGTGGTCAG-3' \\
\hline & $11 \mathrm{R}^{*+}$ & 5'-CACCTCGTCCTACCCCTCG-3' \\
\hline \multirow[t]{2}{*}{12} & $12 \mathrm{~F}^{*+}$ & 5'-GGCTGGAGTGTGGAGGGATG-3' \\
\hline & $12 R^{*}+$ & $5^{\prime}$-CCTCCCATGACGTGCAGGG-3' \\
\hline
\end{tabular}


Table 2. Summary of clinical description of patients with LMNA mutations

\begin{tabular}{|c|c|c|c|c|c|c|c|c|c|}
\hline ID\# & $\begin{array}{c}\angle M N A \\
\text { mutation }\end{array}$ & Gender & $\begin{array}{l}\text { Age of } \\
\text { onset }\end{array}$ & $\begin{array}{c}\text { Age of } \\
\text { diagnosis }\end{array}$ & Origin & Skeletal muscle involvement & Contractures & Cardiac involvement & Other information \\
\hline \multicolumn{10}{|c|}{$\nabla$ Novel mutations } \\
\hline 91 & p.R119R & M & Childhood & $\begin{array}{l}\text { Died at } \\
\text { age } 45\end{array}$ & Familial & $\begin{array}{l}\text { Progressive proximal leg weakness; } \\
\text { LGMD phenotype }\end{array}$ & Heel cord & $\begin{array}{l}\text { Mild dilated cardiomyopathy; LVEF, } 42 \% \text { and cardiac conduction } \\
\text { disease; pacemaker at age 33; died of heart failure at age } 45\end{array}$ & $\begin{array}{l}\text { Weakness and pacemaker in mother; } \\
\text { sudden cardiac death in brother (age 5); } \\
\text { cardiac arrest (in 40's) in maternal } \\
\text { grandfather, uncle and aunt }\end{array}$ \\
\hline 3734 & p.R189P & M & 10 & 33 & Sporadic* & Limb-girdle, proximal upper & Neck and elbow (age 14) & Primary AV block and palpitations at age 22 & n.a. \\
\hline 2952 & p.R190dup & $\mathrm{F}$ & n.a. & 30 & Familial & Generalized & None & Atrial standstill, ventricular arrythmia & n.a. \\
\hline 8542 & p.F206L & M & n.a. & 57 & Familial & Generalized & n.a. & Cardiac conduction defect & n.a. \\
\hline 8434 & p.S268P & M & n.a. & 17 & Familial & Proximal lower weakness & Elbow and achilles tendon & n.a. & n.a. \\
\hline 2018 & p.K270K & M & n.a. & 24 & n.a. & n.a. & n.a. & Cardiomyopathy and conduction disorder & Initially diagnosed with BMD \\
\hline 778 & p.K270K & M & 5 & 26 & Sporadic* & $\begin{array}{l}\text { EDMD phenotype; Limb-girdle, proximal } \\
\text { upper, distal lower }\end{array}$ & Elbow and ankle & $\begin{array}{l}\text { Cardiac involvement age } 25 \text {, prolonged PR-interval which slowly } \\
\text { lengthened until at age } 31 \text { developed atrial fibrillation and } \\
\text { cardiomyopathy; pacemaker at age } 31\end{array}$ & Muscle biopsy age 8 - myocyte apoptosis. \\
\hline $33^{n}$ & $\begin{array}{l}\text { c.IVS4+1G>A } \\
(\text { c. } 810+1 \mathrm{G}>\mathrm{A})\end{array}$ & M & 2 & 15 & Familial & Proximal and distal weakness & Elbow, neck and rigid spine & n.a. & n.a. \\
\hline 6298 & p.S295P & $\mathrm{F}$ & n.a. & 47 & Familial & Proximal weakness & Generalized & Cardiomyopathy with conduction system defects & n.a. \\
\hline 116 & p.Q355del & $\mathrm{F}$ & n.a. & 33 & Familial & $\begin{array}{l}\text { Atrophy of deltoid, triceps, trapezius and } \\
\text { proximal legs muscles and calf } \\
\text { hypertrophy }\end{array}$ & n.a. & $\begin{array}{l}\text { First degree heart block at age 20; mild AV dysfunction on bundle } \\
\text { studies }\end{array}$ & n.a. \\
\hline 2785 & p.E361K & $\mathrm{F}$ & $<5$ & 12 & Familial & EDMD phenotype & $\begin{array}{l}\text { Ankle, achilles tendon and } \\
\text { elbow }\end{array}$ & n.a. & $\begin{array}{l}\text { Cardiomyopathy in mother who received a } \\
\text { heart transplant }\end{array}$ \\
\hline 7975 & $\begin{array}{l}\text { c.IVS6-2A>G } \\
\text { (c.1159-2A>G) }\end{array}$ & M & n.a. & 41 & Sporadic & $\begin{array}{l}\text { EDMD phenotype; moderate proximal } \\
\text { upper, distal lower and limb-girdle } \\
\text { weakness }\end{array}$ & $\begin{array}{l}\text { Elbow (severe), neck and } \\
\text { ankle (minimal) }\end{array}$ & Cardiac conduction defect, pacemaker fitted & n.a. \\
\hline $342^{n}$ & p.G449D & M & 2 & 9 & Familial & $\begin{array}{l}\text { Limb-girdle, proximal upper and distal } \\
\text { lower weakness }\end{array}$ & $\begin{array}{l}\text { Neck, elbow (age 3) and } \\
\text { ankle (age 9) }\end{array}$ & n.a. & n.a. \\
\hline 9106 & p.L454P & $\mathrm{F}$ & 7 & 21 & Sporadic & $\begin{array}{l}\text { Limb-girdle, proximal upper and distal } \\
\text { lower weakness }\end{array}$ & $\begin{array}{l}\text { Ankle (age 7), elbow and } \\
\text { neck (age 12) }\end{array}$ & Cardiac involvement at age 22 & Non-ambulatory at age 14 \\
\hline 7461" & p.W467R & $\mathrm{F}$ & $<3$ & 5 & Sporadic & $\begin{array}{l}\text { Limb-girdle, proximal upper and distal } \\
\text { lower weakness }\end{array}$ & $\begin{array}{l}\text { Ankle (<age 3) and elbow } \\
\text { (age 5) }\end{array}$ & n.a. & Clinical diagnosis of LGMD vs. CMD \\
\hline 2660 & $\begin{array}{l}\text { c.IVS } 8+1 \mathrm{G}>\mathrm{A} \\
\text { (c. } 1488+1 \mathrm{G}>\mathrm{A})\end{array}$ & M & n.a. & 17 & Sporadic & 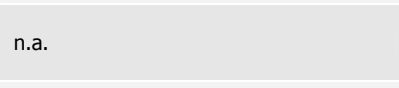 & ( & Pacemaker at age 24 which was replaced at age 30 & $\begin{array}{l}\text { Patient needed a cane and a scoot for } \\
\text { ambulation; died in his early } 30 \text { s (death } \\
\text { possibly unrelated to EDMD) }\end{array}$ \\
\hline \multicolumn{10}{|c|}{$\nabla$ Recurrent mutations } \\
\hline $6537^{\natural}$ & p.N39S & M & $\begin{array}{c}<20 \\
\text { months }\end{array}$ & $\begin{array}{l}\text { Died at } \\
\text { age } 13\end{array}$ & Sporadic* & $\begin{array}{l}\text { Limb-girdle, proximal upper and distal } \\
\text { lower weakness }\end{array}$ & $\begin{array}{l}\text { Ankle (<age 4), knee (age } \\
\text { 7), neck and elbow (age 9) }\end{array}$ & $\begin{array}{l}\text { Right bundle branch block, AV block, atrial flutter, atrial fibrillation } \\
\text { age } 7 \text {, pacemaker at age } 13\end{array}$ & $\begin{array}{l}\text { In wheelchair at age 4; patient died at age } \\
13 \text { of cardiac failure }\end{array}$ \\
\hline 5182 & p.Y45C & M & n.a. & 15 & Sporadic & n.a. & n.a. & $\begin{array}{l}\text { Severe dilated cardiomyopathy associated with muscular } \\
\text { dystrophy, atrial flutter/fibrillation }\end{array}$ & n.a. \\
\hline 563 & p.T150P & $\mathrm{F}$ & n.a. & 38 & Familial & Progressive limb weakness & Neck and elbow & Cardiac arrhythmia at age 22 & n.a. \\
\hline 7897 & p.R249W & M & п.а. & 6 & Familial? & Wasting of humeral muscles & Neck & n.a. & \\
\hline $61^{\pi}$ & p.R249W & M & 1 & 10 & n.a. & $\begin{array}{l}\text { Wasting/weakness of biceps, triceps, } \\
\text { brachii }\end{array}$ & Elbow and ankle & n.a. & $\begin{array}{l}\text { Initially diagnosed with FSHD; } \\
\text { asymptomatic mother, grandfather with } \\
\text { cardiac abnormalities }\end{array}$ \\
\hline $8281^{1}$ & p.R249W & $\mathrm{F}$ & $<1$ & 13 & Sporadic & $\begin{array}{l}\text { Limb-girdle, proximal upper and distal } \\
\text { lower weakness }\end{array}$ & $\begin{array}{l}\text { Ankle (<age 3), elbow (age } \\
\text { 6) and neck (age 11) }\end{array}$ & $\begin{array}{l}\text { Primary AV block, prolonged PR-interval (age 6), prolapse of mitral } \\
\text { valve with mitral insufficiency }\end{array}$ & $\begin{array}{l}\text { Initially diagnosed with Spinal muscular } \\
\text { atrophy }\end{array}$ \\
\hline $3^{*}$ & $\begin{array}{l}\text { p.R249W; } \\
\text { p.R644C }\end{array}$ & $\mathrm{F}$ & $<2$ & 12 & Sporadic & n.a. & Elbow and knee (age 5) & $\begin{array}{l}\text { Mild ventricular enlargement with normal function at age } 10, \text { no } \\
\text { cardiac disease or atrial arrythmias at age } 18\end{array}$ & Non-ambulatory at age 5 \\
\hline 9696 & p.R249Q & $\mathrm{F}$ & п.а. & 26 & Sporadic & $\begin{array}{l}\text { Proximal and distal upper and lower } \\
\text { extremity weakness }\end{array}$ & Neck, elbows and knees & 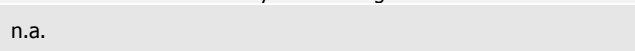 & n.a. \\
\hline
\end{tabular}




\begin{tabular}{|c|c|c|c|c|c|c|c|c|c|}
\hline $167^{\pi}$ & p.R249Q & $\mathrm{F}$ & $<2$ & 28 & Familial & $\begin{array}{l}\text { CMD phenotype; distal and upper lower } \\
\text { extremity weakness, facial weakness }\end{array}$ & Elbow & n.a. & Congenital cataracts, nystagmus, glaucoma \\
\hline 1943 & p.L271P & M & п.а. & 12 & Familial & Humeroperoneal weakness & Elbow and tibialis anterior & Cardiomypathy & n.a. \\
\hline 2111 & p.Q294P & $\mathrm{F}$ & n.a. & 33 & Familial & EDMD phenotype & n.a. & n.a. & n.a. \\
\hline $149^{\prime \prime}$ & p.S303P & M & $<2$ & 16 & Sporadic & Mild proximal upper and lower weakness & n.a. & $\begin{array}{l}\text { Normal sinus rhythm borderline prolonged PR-interval with } \\
\text { occasional premature supraventricular complexes, poor R-wave } \\
\text { progression }\end{array}$ & n.a. \\
\hline $2570^{\natural}$ & p.E358K & M & n.a. & 13 & Sporadic & $\begin{array}{l}\text { Proximal upper, distal lower and limb- } \\
\text { girdle weakness; }\end{array}$ & Neck, elbow, ankle and knee & Dysrhythmia with prolonged PR-interval (age 13) & Wheelchair at age 5 \\
\hline $8419^{n}$ & p.E358K & $\mathrm{F}$ & n.a. & 7 & Familial & Severe EDMD phenotype & n.a. & n.a. & n.a. \\
\hline $26^{\pi}$ & p.E358K & M & 2 & 7 & Sporadic & $\begin{array}{l}\text { Proximal and distal lower extremity } \\
\text { weakness }\end{array}$ & Elbow, ankle, knee and hip & n.a. & n.a. \\
\hline 2631 & p.R386K & M & n.a. & 30 & Sporadic & n.a. & n.a. & n.a. & n.a. \\
\hline 5653 & p.R386K & $\mathrm{F}$ & n.a. & 33 & n.a. & EDMD phenotype & n.a. & n.a. & n.a. \\
\hline 7309 & p.R453W & M & n.a. & 24 & Familial & Mild proximal weakness; & Neck and heel cord & $\begin{array}{l}\text { Echocardiogram shows mildly enlarged left atrium and ventricle, } \\
\text { mild global hypokinesis and reduced systolic function, estimated } \\
\text { LVEF } 45 \%\end{array}$ & CK level 2607U/L \\
\hline 565 & p.R453W & M & n.a. & 36 & n.a. & EDMD phenotype & n.a. & First degree heart block & n.a. \\
\hline 2975 & p.R453W & M & n.a. & 32 & Sporadic & Limb-girdle, proximal upper, distal lower & Neck, elbow, ankle and knee & Beta blockers at age 22, pacemaker at age 32 & Wheelchair at age 14 \\
\hline 5176 & p.R453W & M & $<4$ & 19 & Sporadic & Limb-girdle, proximal upper, distal lower & Neck, elbow and ankle & No cardiac involvement & \\
\hline 1283 & p.R453W & $\mathrm{F}$ & 6 & 28 & Familial & Leg weakness (foot-drop like gait) & Elbow & EMG-diffuse myopathic process; cardiac involvement & $\begin{array}{l}\text { Spinal fusion for sever thoracic-lumbar } \\
\text { scoliosis (age 20); normal muscle biopsy } \\
\text { (age 22) and normal CK level }\end{array}$ \\
\hline 68 & p.R453W & M & 3 & 7 & Sporadic & $\begin{array}{l}\text { LGMD phenotype; proximal lower } \\
\text { extremity weakness }\end{array}$ & Hip & Normal electrocardiography & $\begin{array}{l}\text { Increased CK level (2012U/L); muscle } \\
\text { biopsy showed scattered hyper-contracted } \\
\text { fibers often associated with a membrane } \\
\text { protein defect }\end{array}$ \\
\hline 1412 & $\begin{array}{l}\text { c.IVS7-2A>G } \\
\text { (c.1381-2A>G) }\end{array}$ & M & n.a. & 17 & Sporadic & EDMD phenotype; muscular atrophy & $\begin{array}{l}\text { Neck extensor, elbow flexor } \\
\text { and ankle (severe), knee } \\
\text { (minimal) }\end{array}$ & n.a. & Scoliosis requiring surgery \\
\hline $6388^{\#}$ & $\begin{array}{l}\text { c.IVS7-1G }>T \\
\text { (c.1381-1G>T); } \\
\text { p.D461Y }\end{array}$ & $\mathrm{F}$ & $<1$ & 6 & Familial & Proximal upper and limb-girdle weakness & Neck, elbow, ankle and knee & $\begin{array}{l}\text { Cardiac catheterization (age 3); suggestive of probably early } \\
\text { cardiomyopathy }\end{array}$ & n.a. \\
\hline 2974 & p.T510Yfs X42 & M & n.a. & 51 & Sporadic & Mild proximal upper weakness at age 50 & Mild elbow contractures & $\begin{array}{l}\text { Arrythmia onset in } 20 \text { s, pacemaker placement recommended at } \\
\text { age } 29 \text {, placed at age } 42 \text { when patient experienced incomplete } \\
\text { heart block, heart transplant at age } 51\end{array}$ & n.a. \\
\hline $7288^{\pi}$ & p.R527P & M & $<3$ & 5 & amilial & Proximal upper and limb-girdle weakness & None & Right bundle branch block diagnosed <age 4 & n.a. \\
\hline 1527 & p.T528K & M & n.a. & 11 & Sporadic & & n.a. & n.a. & \\
\hline 1200 & p.T528R & M & n.a. & 12 & n.a. & & n.c & n.a. & n.a. \\
\hline $2257^{\Uparrow}$ & p.T528R & $\mathrm{F}$ & 1 & 12 & Sporadic & $\begin{array}{l}\text { Congenital myopathy phenotype; distal } \\
\text { lower weakness }\end{array}$ & $\begin{array}{l}\text { Bilateral elbow contractures } \\
\text { (age 11), neck, ankle }\end{array}$ & Normal EMG, myopathic biopsy, no cardiac issues at age 11 & $\begin{array}{l}\text { Progressive arthrogryposis, increased CK } \\
\text { level }\end{array}$ \\
\hline 2743 & p.R541S & M & n.a. & 13 & Familial & 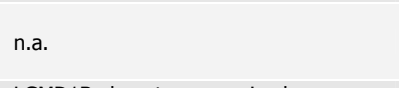 & n.a. & $\begin{array}{l}\text { Dilated cardiomyopathy; congestive heart failure requiring } \\
\text { transplant }\end{array}$ & $\begin{array}{l}\text { Family history of various degrees of DCM } \\
\text { and LGMD1B, loss of adipose tissue in } \\
\text { females }\end{array}$ \\
\hline 198 & p.R541P & $\mathrm{F}$ & Childhood & 52 & Familial & $\begin{array}{l}\text { LGMD1B phenotype; proximal upper, } \\
\text { limb-girdle, distal lower weakness, loss } \\
\text { of muscle mass (age 19) }\end{array}$ & Elbow, knee & Atrial fibrillation & One child with EDMD, other with LGMD1B \\
\hline 853 & p.G602S & M & n.a. & 6 & Sporadic & Limb-girdle weakness (age 11) & $\begin{array}{l}\text { Hamstrings, elbows, neck } \\
\text { and rigid spine }\end{array}$ & Cardiac defect (atrial septal defect) & n.a. \\
\hline $51^{\pi}$ & p.R644C & M & Birth & 19 & Sporadic & $\begin{array}{l}\text { Weakness and hypotonia of the proximal } \\
\text { musculature of the upper and lower } \\
\text { extremities and broad based gait (age 3) }\end{array}$ & Elbow and ankle & n.a. & $\begin{array}{l}\text { Progression until age } 10 \text {, then stabilization; } \\
\text { CK level } 1400 \mathrm{U} / \mathrm{L}\end{array}$ \\
\hline
\end{tabular}

II Patients with a severe phenotype and single LMNA mutation

\# Compound heterozygous patients with a severe phenotype

* Patients confirmed to be sporadic cases of EDMD by molecular analysis of family members including parents and siblings

Abbreviations: n.a., data not available; AV, Atrioventricular; CK, Creatine kinase; EMG, Electromyography; LVEF, Left ventricular ejection fraction 
Table 3. Summary of $L M N A$ mutations and encoded protein

\begin{tabular}{|c|c|c|c|c|c|c|}
\hline ID\# & LMNA mutation & $\begin{array}{l}\text { LMNA } \\
\text { exon/ } \\
\text { intron }\end{array}$ & $\begin{array}{l}\text { Predicted } \\
\text { amino acid } \\
\text { change }\end{array}$ & $\begin{array}{l}\text { Mutation } \\
\text { type }\end{array}$ & $\begin{array}{l}\text { Protein } \\
\text { domain } \\
\text { affected }\end{array}$ & Ref. for published mutations \\
\hline \multicolumn{7}{|c|}{$\nabla$ Novel mutations } \\
\hline 91 & c.357C $>\mathrm{T}$ & 2 & p.R119R & Silent & Coil 1b & Novel \\
\hline 3734 & c.566_567delinsCC & 3 & p.R189P & Missense & Coil $1 b$ & Novel \\
\hline 2952 & c.568_570dup & 3 & p.R190dup & $\begin{array}{l}\text { Duplication } \\
\text { (In frame } \\
\text { insertion) }\end{array}$ & Coil 1b & Novel \\
\hline 8542 & c. $618 \mathrm{C}>\mathrm{G}$ & 3 & p.F206L & Missense & Coil $1 b$ & Novel \\
\hline 8434 & c. $802 \mathrm{~T}>\mathrm{C}$ & 4 & p.S268P & Missense & Coil $2 b$ & Novel \\
\hline 2018 & c. $810 \mathrm{G}>\mathrm{A}$ & 4 & p.K270K & Silent & Coil 2b & Novel \\
\hline 778 & c. $810 \mathrm{G}>\mathrm{A}$ & 4 & p.K270K & Silent & Coil $2 b$ & Novel \\
\hline 33 & $\begin{array}{l}\text { c.IVS4+1G>A } \\
(\text { c. } 810+1 G>A)\end{array}$ & IVS 4 & & Splice site & & Novel \\
\hline 6298 & c. $883 \mathrm{~T}>\mathrm{C}$ & 5 & p.S295P & Missense & Coil $2 b$ & Novel \\
\hline 116 & c.1064_1066del & 6 & p.Q355del & $\begin{array}{l}\text { In frame } \\
\text { deletion }\end{array}$ & Coil $2 b$ & Novel \\
\hline 2785 & c. $1081 \mathrm{G}>\mathrm{A}$ & 6 & p.E361K & Missense & Coil 2b & Novel \\
\hline 7975 & $\begin{array}{l}\text { c.IVS6-2A>G } \\
\text { (c.1159-2A>G) }\end{array}$ & IVS 6 & & Splice site & & Novel \\
\hline 342 & c. $1346 \mathrm{G}>\mathrm{A}$ & 7 & p.G449D & Missense & Tail (Ig-fold) & Novel \\
\hline 9106 & c. $1361 \mathrm{~T}>\mathrm{C}$ & 7 & p.L454P & Missense & Tail (Ig-fold) & Novel \\
\hline 7461 & c. $1399 \mathrm{~T}>\mathrm{C}$ & 8 & p.W467R & Missense & Tail (Ig-fold) & Novel \\
\hline 2660 & $\begin{array}{l}\text { c.IVS8+1G }>A \\
(c .1488+1 G>A)\end{array}$ & IVS 8 & & Splice site & & Novel \\
\hline \multicolumn{7}{|c|}{$\nabla$ Recurrent mutations } \\
\hline 6537 & C. $116 A>G$ & 1 & p.N39S & Missense & Coil 1a & (Benedetti, et al., 2007; Quijano-Roy, et al., 2008) \\
\hline 5182 & c. $134 \mathrm{~A}>\mathrm{G}$ & 1 & p.Y45C & Missense & Coil $1 \mathrm{a}$ & (Bonne, et al., 2000) \\
\hline 563 & c. $448 \mathrm{~A}>\mathrm{C}$ & 2 & p.T150P & Missense & Coil $1 b$ & (Felice, et al., 2000) \\
\hline 7897 & c. $745 C>T$ & 4 & p.R249W & Missense & Coil 2a & (Quijano-Roy, et al., 2008) \\
\hline 61 & c. $745 \mathrm{C}>\mathrm{T}$ & 4 & p.R249W & Missense & Coil 2a & same as above \\
\hline 8281 & c. $745 \mathrm{C}>\mathrm{T}$ & 4 & p.R249W & Missense & Coil 2a & same as above \\
\hline 3 & $\begin{array}{l}\text { c. } 745 C>T \\
\text { c. } 1930 \mathrm{C}>\mathrm{T}\end{array}$ & $\begin{array}{l}4 ; \\
11\end{array}$ & $\begin{array}{l}\text { p.R249W; } \\
\text { p.R644C }\end{array}$ & Missense & $\begin{array}{l}\text { Coil 2a; } \\
\text { Tail (Lamin A } \\
\text { specific) }\end{array}$ & $\begin{array}{l}\text { (Quijano-Roy, et al., 2008); (Csoka, et al., 2004; Genschel, et al., 2001; } \\
\text { Mercuri, et al., 2005; Muntoni, et al., 2006; Pasotti, et al., 2008; Perrot, et } \\
\text { al., 2009; Rankin, et al., 2008) }\end{array}$ \\
\hline 9696 & c. $746 \mathrm{G}>\mathrm{A}$ & 4 & p.R249Q & Missense & Coil $2 a$ & $\begin{array}{l}\text { (Benedetti, et al., 2007; Bonne, et al., 2000; Boriani, et al., 2003; Brown, et } \\
\text { al., 2001; Ki, et al., 2002; Muchir, et al., 2004; Raffaele Di Barletta, et al., } \\
\text { 2000; Rudenskaya, et al., 2008; Vytopil, et al., 2003) }\end{array}$ \\
\hline 167 & c.746G $>A$ & 4 & p.R249Q & Missense & Coil 2a & same as above \\
\hline 1943 & c. $812 \mathrm{~T}>\mathrm{C}$ & 5 & p.L271P & Missense & Coil $2 b$ & (Kichuk Chrisant, et al., 2004) \\
\hline 2111 & c. $881 \mathrm{~A}>\mathrm{C}$ & 5 & p.Q294P & Missense & Coil 2b & (Bonne, et al., 2000) \\
\hline 149 & C. $907 \mathrm{~T}>\mathrm{C}$ & 5 & p.S303P & Missense & Coil $2 b$ & (Onishi, et al., 2002) \\
\hline 2570 & c. $1072 \mathrm{G}>\mathrm{A}$ & 6 & p.E358K & Missense & Coil $2 b$ & $\begin{array}{l}\text { (Benedetti, et al., 2007; Bonne, et al., 2000; Brown, et al., 2001; Mercuri, et } \\
\text { al., 2004; Quijano-Roy, et al., 2008) }\end{array}$ \\
\hline 8419 & c. $1072 \mathrm{G}>\mathrm{A}$ & 6 & p.E358K & Missense & Coil $2 b$ & same as above \\
\hline 26 & c. $1072 \mathrm{G}>\mathrm{A}$ & 6 & p.E358K & Missense & Coil $2 b$ & same as above \\
\hline 2631 & c. $1157 \mathrm{G}>\mathrm{A}$ & 6 & p.R386K & Missense & Coil $2 b$ & (Bonne, et al., 2000; Boriani, et al., 2003) \\
\hline 5653 & c. $1157 \mathrm{G}>\mathrm{A}$ & 6 & p.R386K & Missense & Coil $2 b$ & same as above \\
\hline 7309 & c. $1357 C>T$ & 7 & p.R453W & Missense & Tail (Ig-fold) & $\begin{array}{l}\text { (Benedetti, et al., 2007; Bonne, et al., 1999; Bonne, et al., 2000; Brette, et } \\
\text { al., 2004; Colomer, et al., 2002; Fidzianska and Glinka, 2006; Golzio, et al., } \\
\text { 2007; Muchir, et al., 2004; Raffaele Di Barletta, et al., 2000; Vytopil, et al., } \\
\text { 2003) }\end{array}$ \\
\hline 565 & c. $1357 C>T$ & 7 & p.R453W & Missense & Tail (Ig-fold) & same as above \\
\hline 2975 & c. $1357 \mathrm{C}>\mathrm{T}$ & 7 & p.R453W & Missense & Tail (Ig-fold) & same as above \\
\hline 5176 & c. $1357 \mathrm{C}>\mathrm{T}$ & 7 & p.R453W & Missense & Tail (Ig-fold) & same as above \\
\hline 1283 & c. $1357 \mathrm{C}>\mathrm{T}$ & 7 & p.R453W & Missense & Tail (Ig-fold) & same as above \\
\hline 68 & c. $1357 \mathrm{C}>\mathrm{T}$ & 7 & p.R453W & Missense & Tail (Ig-fold) & same as above \\
\hline 1412 & $\begin{array}{l}\text { c.IVS7-2A>G } \\
(\text { c. } 1381-2 A>G)\end{array}$ & IVS 7 & & Splice site & & (Quijano-Roy, et al., 2008) \\
\hline 6388 & $\begin{array}{l}\text { c.IVS7-1G }>\mathrm{T} \\
(\text { c. } 1381-1 \mathrm{G}>\mathrm{T}) \\
\text { c. } 1381 \mathrm{G}>\mathrm{T}\end{array}$ & $\begin{array}{l}\text { IVS } 7 / \\
\text { exon } 8\end{array}$ & p.D461Y & $\begin{array}{l}\text { Splice site; } \\
\text { Missense }\end{array}$ & Tail (Ig-fold) & (Bakay, et al., 2006) \\
\hline 2974 & c.1526dup & 9 & p.T510YfsX42 & Frame shift & Tail (Ig-fold) & (Arbustini, et al., 2005) \\
\hline 7288 & c. $1580 G>C$ & 9 & p.R527P & Missense & Tail (Ig-fold) & $\begin{array}{l}\text { (Benedetti, et al., 2007; Bonne, et al., 1999; Bonne, et al., 2000; Brown, et } \\
\text { al., 2001; Raffaele Di Barletta, et al., 2000; van der Kooi, et al., 2002) }\end{array}$ \\
\hline 1527 & c. $1583 \mathrm{C}>\mathrm{A}$ & 9 & p.T528K & Missense & Tail (Ig-fold) & $\begin{array}{l}\text { (Benedetti, et al., 2007; Bonne, et al., 2000; Fokkema, et al., 2005; Raffaele } \\
\text { Di Barletta, et al., 2000) }\end{array}$ \\
\hline 1200 & C. $1583 C>G$ & 9 & p.T528R & Missense & Tail (Ig-fold) & (Fokkema, et al., 2005; Vytopil, et al., 2003) \\
\hline 2257 & c. $1583 C>G$ & 9 & p.T528R & Missense & Tail (Ig-fold) & same as above \\
\hline 2743 & c. $1621 C>A$ & 10 & p.R541S & Missense & Tail & (Sylvius, et al., 2005) \\
\hline 198 & c. $1622 \mathrm{G}>\mathrm{C}$ & 10 & p.R541P & Missense & Tail & (van Tintelen, et al., 2007) \\
\hline 853 & c. $1804 \mathrm{G}>\mathrm{A}$ & 11 & p.G602S & Missense & $\begin{array}{l}\text { Tail (Lamin A } \\
\text { specific) }\end{array}$ & (Bakay, et al., 2006; Young, et al., 2005) \\
\hline 51 & c. $1930 \mathrm{C}>\mathrm{T}$ & 11 & p.R644C & Missense & $\begin{array}{l}\text { Tail (Lamin A } \\
\text { specific) }\end{array}$ & $\begin{array}{l}\text { (Csoka, et al., 2004; Genschel, et al., 2001; Mercuri, et al., 2005; Muntoni, et } \\
\text { al., 2006; Pasotti, et al., 2008; Perrot, et al., 2009; Rankin, et al., 2008) }\end{array}$ \\
\hline
\end{tabular}

LMNA GenBank Accession Number RefSeq NM_170707.2; Nucleotide numbering reflects cDNA numbering with +1 corresponding to the A of the ATG translation initiation codon in the reference sequence, according to journal guidelines (www.hgvs.org/mutnomen). The initiation codon is codon 1. 


\section{Figure 1}
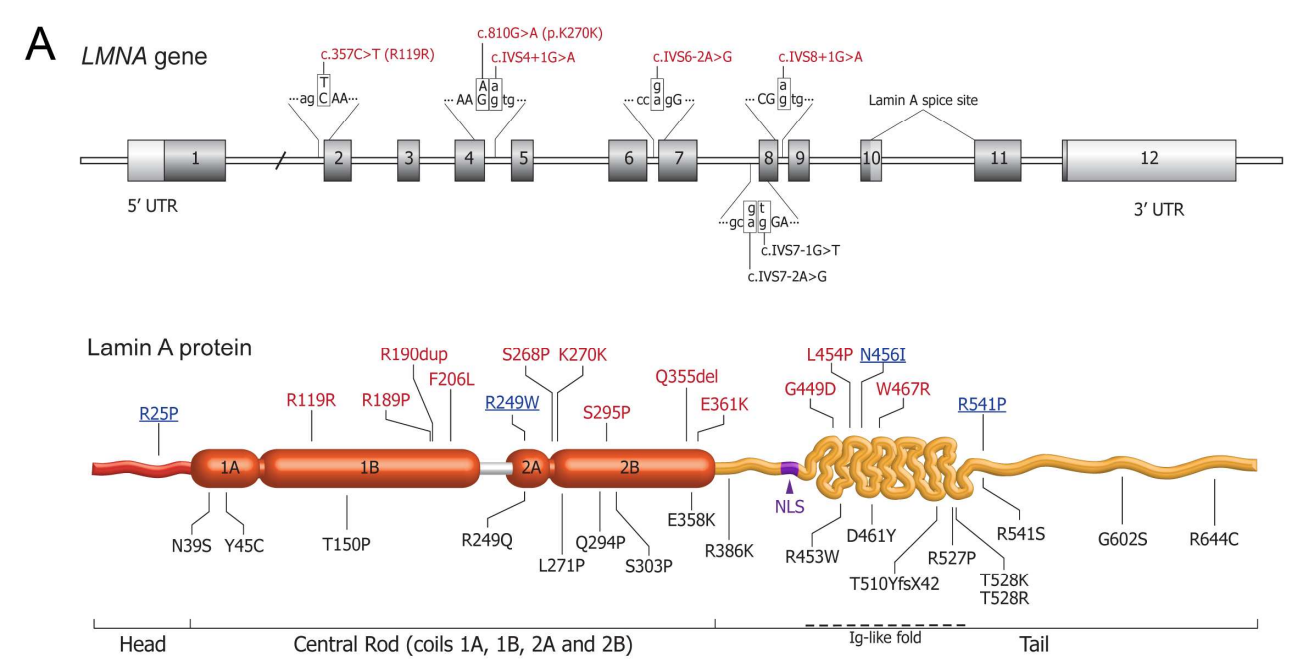

B

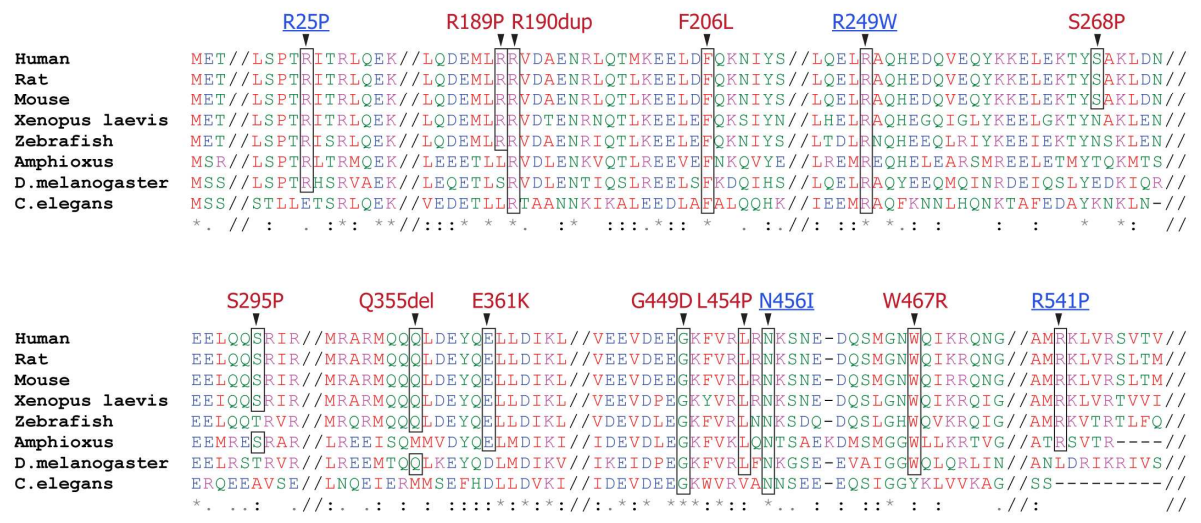

$200 \times 210 \mathrm{~mm}(300 \times 300 \mathrm{DPI})$

John Wiley \& Sons, Inc. 


\section{Figure 2}

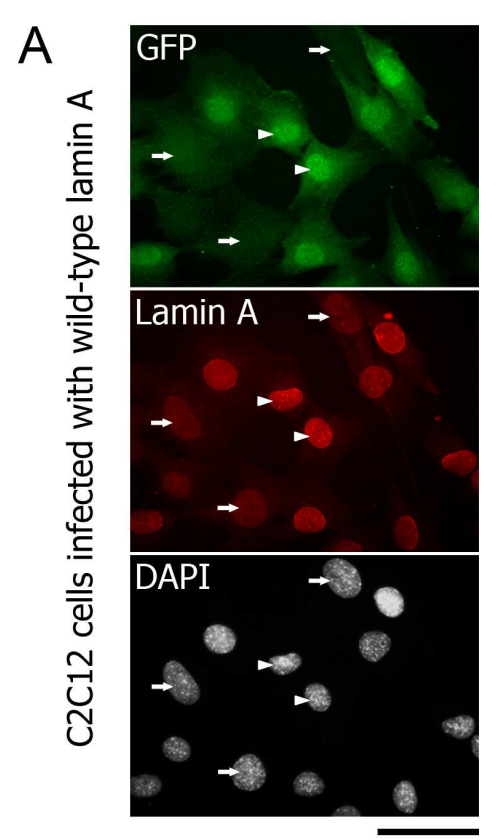

D

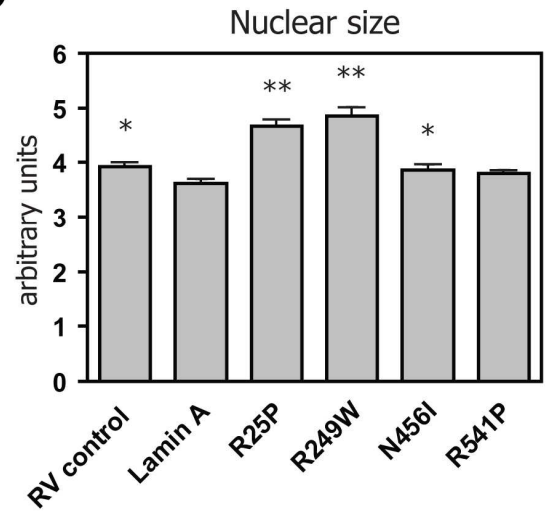

C

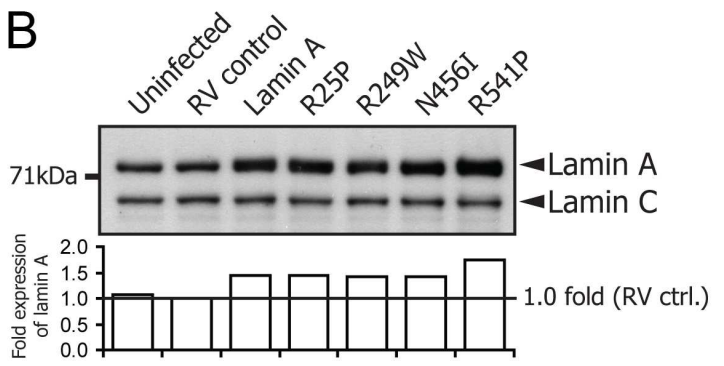

$28 \mathrm{kDa}-2-\infty-6-6$ 48kDa

pMSCV-laminA-IRES-eGFP vector

\begin{tabular}{|l|l|l|l|}
\hline $5^{\prime}$ LTR & $\Psi=$ Lamin A & IRES & eGFP \\
\hline & $-3{ }^{\prime}$ LTR \\
\hline
\end{tabular}

$E$

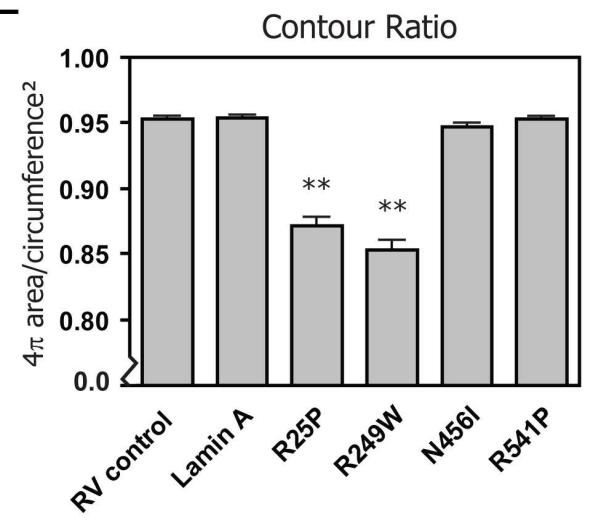

$174 \times 214 \mathrm{~mm}(300 \times 300$ DPI $)$

John Wiley \& Sons, Inc. 


\section{Figure 3}

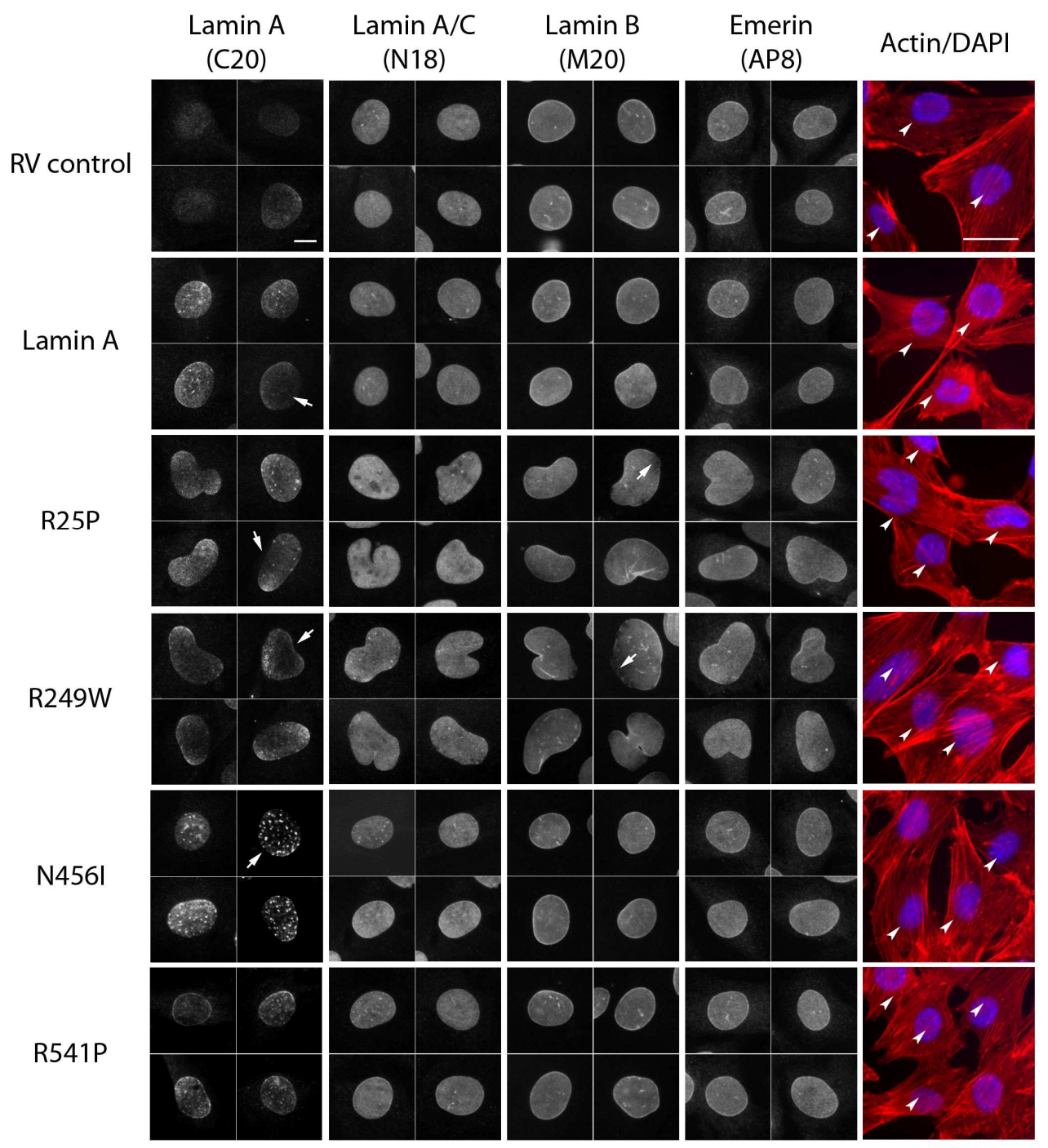

$181 \times 214 \mathrm{~mm}(300 \times 300$ DPI $)$

John Wiley \& Sons, Inc. 
Figure 4
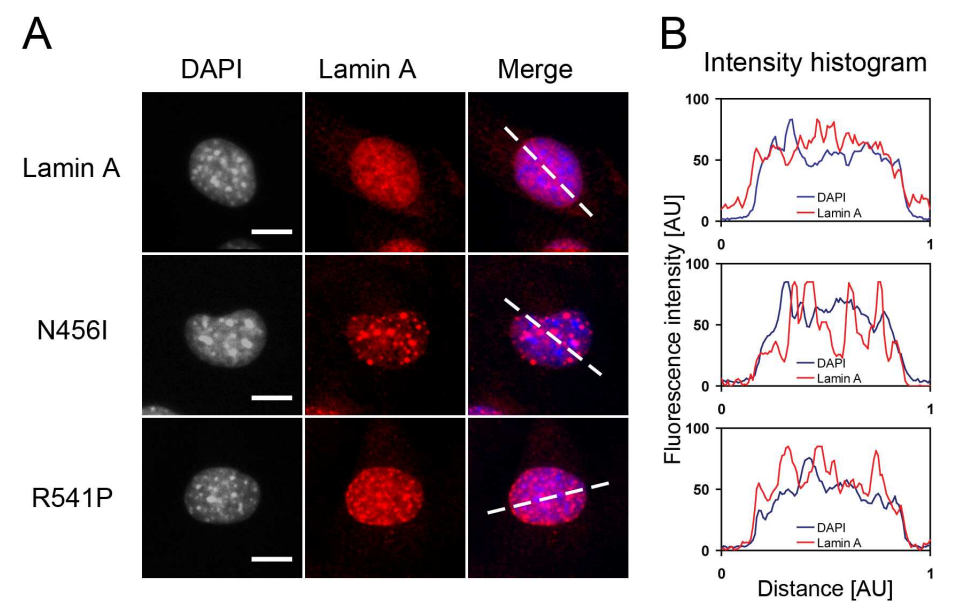

C

D

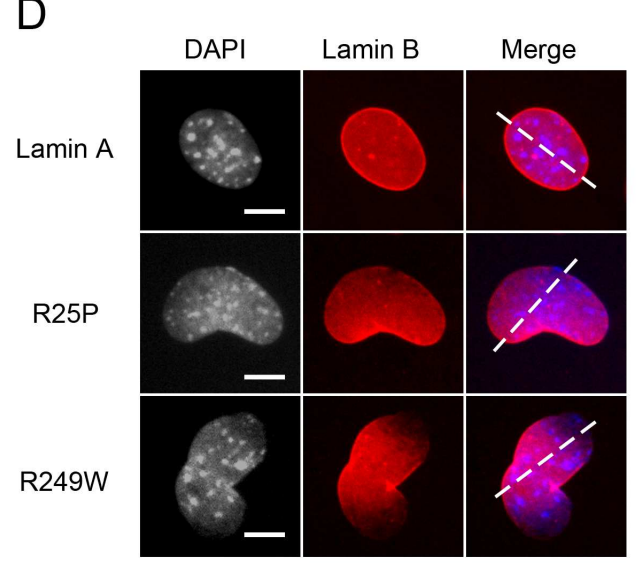

E Intensity histogram

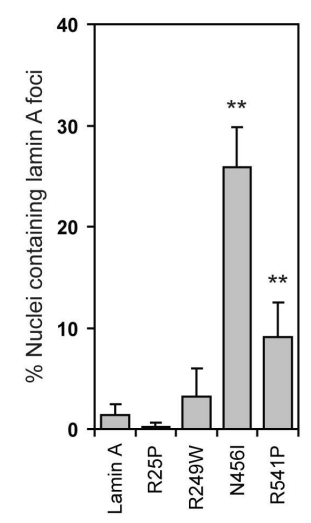

F
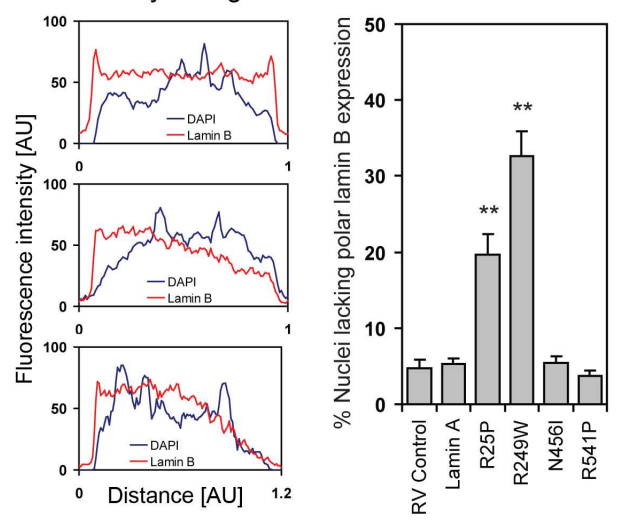

$206 \times 218 \mathrm{~mm}(300 \times 300$ DPI $)$

John Wiley \& Sons, Inc. 
Figure 4

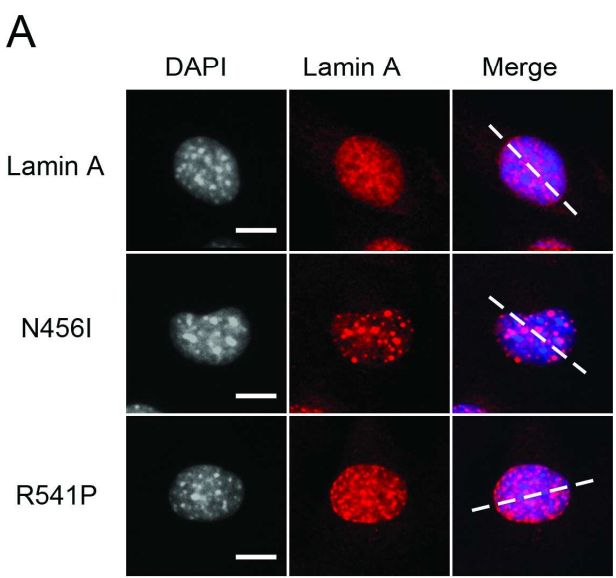

B Intensity histogram

C
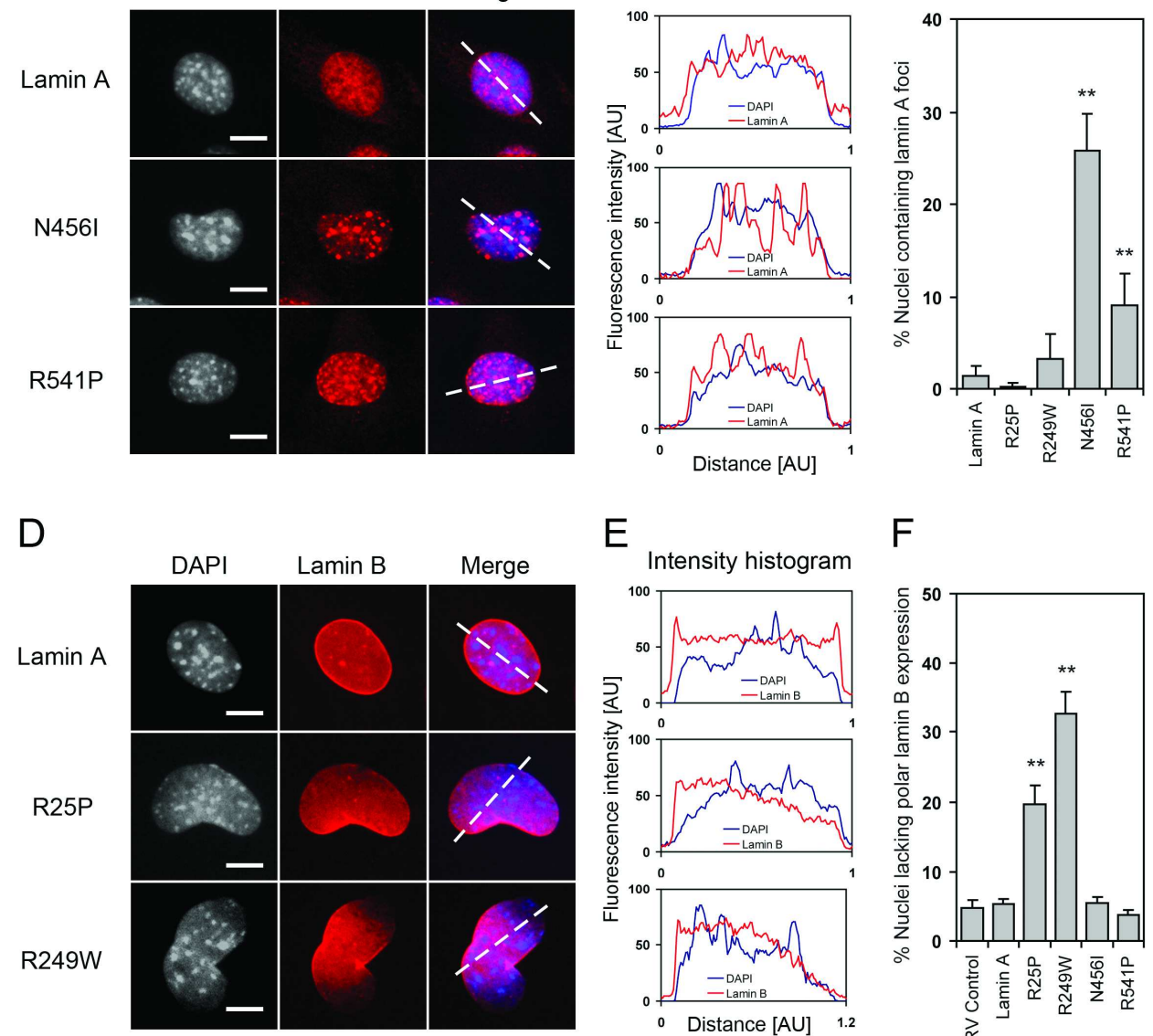

E Intensity histogram

$\mathrm{F}$
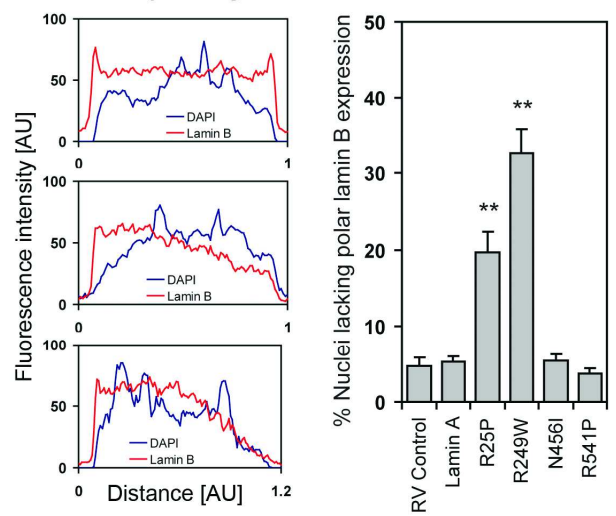

$206 \times 218 \mathrm{~mm}(300 \times 300 \mathrm{DPI})$

John Wiley \& Sons, Inc. 